\title{
A box-model of carrying capacity of the Thau lagoon in the context of ecological status regulations and sustainable shellfish cultures
}

\author{
Pete Romain ${ }^{1,}{ }^{*}$, Guyondet Thomas ${ }^{2}$, Bec Beatrice ${ }^{1}$, Derolez Valerie ${ }^{1}$, Cesmat Ludovic ${ }^{3}$, \\ Lagarde Franck ${ }^{1}$, Pouvreau Stephane ${ }^{4}$, Fiandrino Annie ${ }^{1}$, Richard Marion ${ }^{1}$
}

\author{
${ }^{1}$ Marine Biodiversity, Exploitation and Conservation (MARBEC). Univ Montpellier, CNRS, Ifremer, IRD, \\ CC093, Place Eugène Bataillon, 34095, Montpellier Cedex 5, Montpellier \& Sète, France \\ 2 Department of Fisheries and Oceans, Gulf Fisheries Center, P.O. Box 5030, Science Branch, \\ Moncton, NB E1C 9B6, Canada \\ 3 Syndicat Mixte du Bassin de Thau, 328, Quai des Moulins-34200 SETE, France \\ 4 Ifremer, Laboratoire des Sciences de I'Environnement Marin (LEMAR), 29840 Argenton-en- \\ Landunvez, France
}

* Corresponding author : Romain Pete, email address : romain.pete@umontpellier.fr

\begin{abstract}
:
The decrease of microbial and nutrient inputs from the watershed has long dominated lagoon ecosystem management objectives. Phytoplankton biomass and abundance have drastically decreased for more than a decade and Zostera meadow have gradually recovered, expressing lagoon ecosystem restoration such as Thau lagoon. Do the progressive achievement of the good ecological status of the Thau lagoon possibly threatens the shellfish industry in terms of production and oyster quality, by reducing the carrying capacity? To provide answers about the right balance to be achieved between conservation and exploitation, a new numerical tool was developed to help in decision-making. We hereby propose to incorporate a Dynamic Energy Budget type shellfish production model to an existing lagoon ecosystem box-model. The influence of different scenarios of nutrient inputs (related to projections of population growth or improvement of treatment plants) and shellfish stocks were tested on oyster performances (production, oyster condition index), carrying capacity of the lagoon and ecological status indices used within the EU Water Framework Directive. Model outputs demonstrated that shellfish production was mainly controlled by nutrient inputs, which depend on hydro-meteorological variability, and specifically by phosphorus and N:P ratios of nutrient inputs. Scenarios tested, however, demonstrated smaller differences of oyster production in comparison to inter-annual variability. The overall ecological status of the lagoon remained in a "good" status with acceptable lagoon-scale phytoplankton depletion, regardless of scenarios, setting the carrying capacity of this ecosystem to be sustainable.
\end{abstract}




\section{Highlights}

- The variability of oyster production is mainly controlled by the hydrometeorology. Waste water treatment plant (WWTP) efficiency affect oyster production, without significantly improving the ecological status of the Thau lagoon. Scenario of oyster stocking density to its authorized maximum triggered an increase of oyster productions at the expenses of thinner oysters with a lower condition index. The Thau lagoon remains an exceptional site for oyster farming associated with "good" ecological status condition and where the carrying capacity was not limiting. Oyster production might be threatened by drastic measures to be undertaken on WWPT, particularly on phosphorus that seems to control primary production in the Thau ecosystem.

Keywords : Shellfish farming, Carrying capacity, Stakeholder implication, Nitrogen and phosphorus inputs, Water frame directive, Ecological indicators, Phytoplankton depletion, Coupled biogeochemicaldeb model 


\section{Introduction}

Rapid expansion of bivalve aquaculture in the last few decades with 17.1 million tons of mollusks produced worldwide (FAO, 2018) plays a key role in local socio-economic developments. FAO therefore promoted, in its recent report, a holistic and integrated ecosystem approach of aquaculture (EAA) to address management issues of sustainable aquaculture. Among the key features of this EEA framework, FAO highlighted: the wide stakeholder participation in planning and implementing; a comprehensive consideration of major components, e.g. aquaculture, socio-economics and environmental, based on "best available knowledge"; and a search for a trade-off between environment/conservation and socio-economic objectives. This rapid growing economic sector has inevitably raised questions of carrying capacity and sustainability (Nunes et al., 2003).

In this context, the concept of the carrying capacity is commonly used as it involves major aspects of integrated ecosystem functioning such as physics, productivity, ecology and socioeconomics (McKindsey et al., 2006). Regarding cultured bivalves, this carrying capacity can be primarily defined as the biomass of a population supported permanently by a given system (Dame and Prins., 1998; Kashiwai, 1998). However, this definition has been successively extended to a maximized production without affecting growth rates (Carver and Mallet, 1990) to a maximized production of marketable cohorts (Bacher et al., 1998) and more recently to a maximized production within the frame of environmental sustainability (Smaal et al., 1997; Ferreira et al., 2008; Byron et al., 2011b; Filgueira et al., 2015). The current consensus is that production carrying capacity represents the stock that maximizes harvests while ecosystem responses or ecological carrying capacity deal with unwanted modifications of phytoplankton abundances, nutrient cycling or organic content in sediments (McKindsey et al., 2006; Grant et al., 2007; Guyondet et al., 2014;). 
Recent research has been promoting use of mathematical models, of various complexity (Dabrowski et al., 2013), to tackle the issues of cultured shellfish management. A lot of efforts have been made in the representation of shellfish modeling from individual based (Gangnery, 2003) to mechanistic (Bourlès et al., 2009; Kooijman, 2010; Alunno-Bruscia et al., 2011) and mixed (Brigolin et al., 2009) models. These individual models are then coupled to ecosystem food web-based models that include most of the relevant biological compartments of aquatic systems (Grangeré et al., 2009; Byron et al., 2011c; Filgueira et al., 2014b). These coupled models can thus be complexified by representing exchanges with the outer world through simple renewal times (Grangeré et al., 2009), box-model (Chapelle et al., 2000; Filgueira and Grant, 2009; Raillard and Menesguen, 1994) and fully spatialized hydrodynamic models (Guyondet et al., 2010). While these models give insights into the carrying capacity of an ecosystem, it is crucial to derive other model outputs to evaluate impacts of shellfish farming on ecosystem functioning.

The Thau lagoon, as many other coastal Mediterranean lagoons, has been experiencing major anthropogenic pressures as it received large nutrient loadings from its watershed (La Jeunesse and Elliott, 2004; Plus et al., 2006). These nutrient inputs have been identified as the main cause of eutrophication issues or dystrophic crisis (Souchu et al., 1998; Harzallah and Chapelle, 2002). Thus, many efforts have been made to reduce nutrient loadings mainly through the installation of waste water treatment plants (WWTP) in the 1970's and their refurbishment later in the 2000's. These works have drastically reduced the amount of nutrient inputs from the watershed and successfully led to reach a current "good" ecological status of water column of the Thau lagoon according to the EU Water Framework Directive (WFD) (EC, 2000; Derolez et al, 2019). These profound changes in the lagoon inputs from the watershed have raised concerns from shellfish farmers. Oyster farming, after having taken precedence over mussel farming in the 1990s, has seen its activity largely impacted by 
juvenile mortality phenomena from 2008 (Pernet et al., 2012), which significantly reduced the overall annual shellfish production. Under current production conditions, long-term observations of farmed oyster performances have shown improved growth rates and condition index, probably linked to a decrease in the oyster stock, despite the decrease in phytoplankton biomass observed (Bec et al., 2018). Considering these recent and important changes in the pressures exerted on the Thau lagoon, an assessment of its ecological carrying capacity for shellfish culture is required. We hereby present a modelling work to address concerns arising from shellfish farmers and consider realistic actions combining the achievement of regulatory constraints and the sustainability of this major socio-economic activity.

The GAMELag model (Pete et al, $t b s$ ) was formerly developed for the Bages-Sigean lagoon, to produce similar ecological indicators as those used in the WFD (European Community, 2000). These indicators have been established as relevant criterion to assess ecological status of a given ecosystem according to different categories from "high" to "very bad". In addition, a dynamic energy budget (DEB) model for the Pacific oyster Crassostrea gigas, formerly developed on the Atlantic coast (Pouvreau et al., 2006; Bernard et al., 2011a), was parameterized for the Thau lagoon and coupled to the GAMELag model. Concomitantly to the model implementation, a major part of the presented work was realized in close partnership with shellfish growers, local and governmental management bodies and scientists. Based on this joint work, management scenarios were established on realistic working hypotheses. The objectives of this work were therefore: 1) to build a carrying capacity model and 2) to test the effects of nitrogen and phosphorus inputs and oyster stocking densities, on oyster performances (condition index, production), carrying capacity and ecological status of the Thau lagoon. This work was carried out in collaboration with managers and farmers to find the right balance between conservation and exploitation for sustainable development of shellfish farming in good ecological status coastal area. 


\section{Material \& Methods}

\subsection{Study site}

Thau lagoon (Figure 1) is located on the south coast of France (43.18'- 43.28'N, 3.30'-

$\left.3.45^{\prime} \mathrm{E}\right)$ and has a total area of $68 \mathrm{~km}^{2}(19,5 \mathrm{~km}$ long by $4.5 \mathrm{~km}$ width $)$ and an average depth of $4 \mathrm{~m}$ (Fiandrino et al., 2017). The lagoon is connected to the sea through two inlets, i.e., the Sète channel in the north (90\% of sea water exchanges) and the Grau de Pisse-Saumes inlet in the south. The Sète channel is $2.4 \mathrm{~km}$ long with a mean cross-section of about $300 \mathrm{~m}^{2}$. The Mediterranean climate is characterised by a wide range of temperatures $\left(5-29{ }^{\circ} \mathrm{C}\right)$ and salinities in the lagoon cover a range of $27-42$ with a low spatial gradient (data from REPHY monitoring network; Fiandrino et al., 2017).

The lagoon has a narrow located between the Balaruc Point and the Barrou Point, separating the lagoon into two basins, the "Petit Etang" to the East and "Grand Etang" to the West. The Grand Etang is the location of shellfish farming activities spread over three areas at the north of this basin (20\% of the lagoon surface). These shellfish farming zones, namely Bouzigues, Mèze and Marseillan (Figure 1), gather around 2800 farming structures (1250 $\mathrm{m}^{2}$ and a total area of $\sim 640$ ha) harbouring growing oyster juveniles (hereafter spat) and adults (hereafter oyster) of the pacific oyster Crassostrea gigas (70\% of the shellfish stocks) and mussel Mytilus galloprovincialis. 


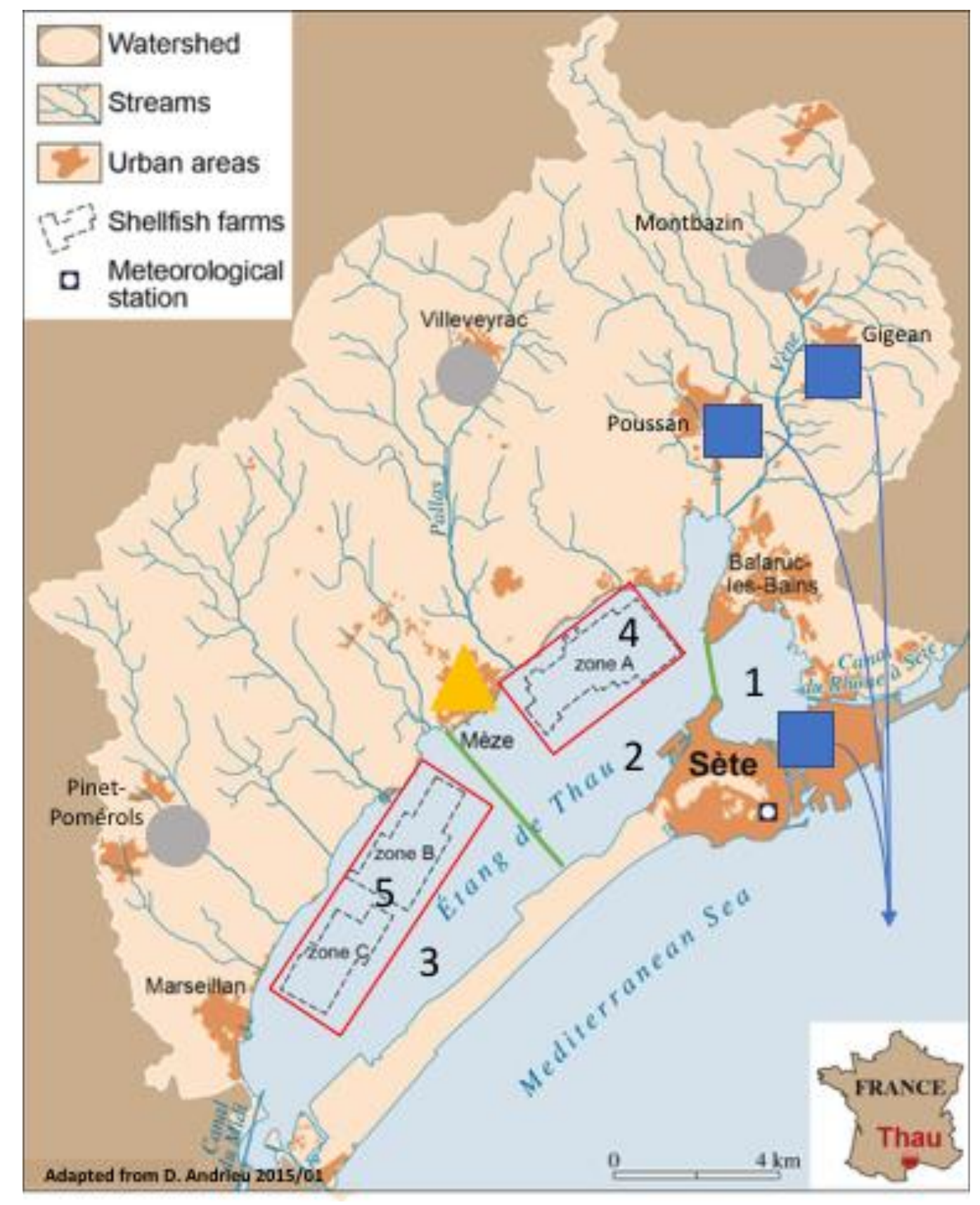

Figure 1. Map of the Thau lagoon and its watershed. WWTP are located by symbols and distinguish WWTP releasing to the sea (squares), using normal abatements (circles) or maximum abatements (triangle). Hydrodynamic frontiers are represented by green lines separating three basins (numbered 1 to 3 ) and shellfish farming area are located by the two red boxes (numbered 4 and 5).

The watershed spreads mainly northward from the lagoon over an area of $280 \mathrm{~km}^{2}$ and is drained by several rivers with intermittent flows. The main tributary (the Vène River) is connected to the Crique de l'Angle area and brings an annual average of $15.1 \mathrm{Mm}^{3}$ of 
freshwater (about $50 \%$ of total flow, ranging from 3.1 to $24.7 \mathrm{Mm}^{3}$ between 2009 and 2016). The population in this watershed amounts to 126604 inhabitants (French National Institute of Statistics and Economical Studies, Insee, 2015) over 14 main cities equipped with waste water treatment plants (WWTP). Five of these towns, Sète, Poussan, Bouzigues, Gigean and Balaruc (Figure 1) are connected to the Sète WWTP which discards effluents 7 km offshore in the Mediterranean Sea. The four other cities, Montbazin, Villeveyrac, Mèze-Loupian and Pinet-Pomerols have their own WWTP releasing effluents into the Thau lagoon.

\subsection{Carrying capacity model}

The GAMELag model (Pete et al, $t b s$ ) was formerly developed for management purposes with regards to water quality assessment under the WFD. GAMELag works on the principle of a box-model, where the lagoon is represented by basins, physically homogeneous, in which the stocks of the different biological compartments are simulated as well as the fluxes of matter (nitrogen $\mathrm{N}$ and phosphorus $\mathrm{P}$ ) connecting these compartments (Figure 2). The lagoon was separated into three main boxes (green boxes, Fig. 1): "Petit Etang” (box 1), East of "Grand Etang" and West of "Grand Etang" (box 2 and 3, respectively on Fig. 1). In order to simplify the model and to be able to compare it with available observations, the Mèze and Marseillan shellfish farming zones were gathered to form box 5, whereas Bouzigues shellfish farming zone formed box 4 (red boxes, Fig. 1).

The hydrodynamic exchanges between box 1 and the Mediterranean Sea and between two adjacent physical boxes are simulated following formalism defined by Gordon et al, 1996 based on daily net residual volumes and mixing volumes. While net residual volumes are state variables of the hydrodynamic module of the GAMELag model, daily time series of mixing volumes at frontiers of physical boxes have to be defined as forcing dataset. The hydrodynamic exchanges between box 4 and physical box 1 and between box 5 and physical 
box 2 only depend on mixing volume, there is no net residual volumes between these boxes. Mixing volume takes into account wind mixing (mainly inside the lagoon) and tide-driven exchange (between lagoon and the sea). These mixing volumes are therefore varying in time. A 3-dimensional hydrodynamic Model for Application at Regional Scale (MARS-3D) was used to compute daily time series of mixing volumes (Lagarde et al., 2019; Lazure and Dumas, 2008). Descriptions of the MARS3D model applied on Thau lagoon and the forcing dataset necessary for simulating water bodies circulation are provided in Fiandrino et al. (2017). Same atmospheric (wind, air temperature, incident radiation) and hydrological (daily average river water fluxes $\left(\mathrm{m}^{3} . \mathrm{s}^{-1}\right)$ from the watershed) are used to force MARS-3D and GAMELag models. Specific dataset were used (sea level elevation in Sete Channel) to force MARS-3D model at the open boundary condition for the simulated period. 


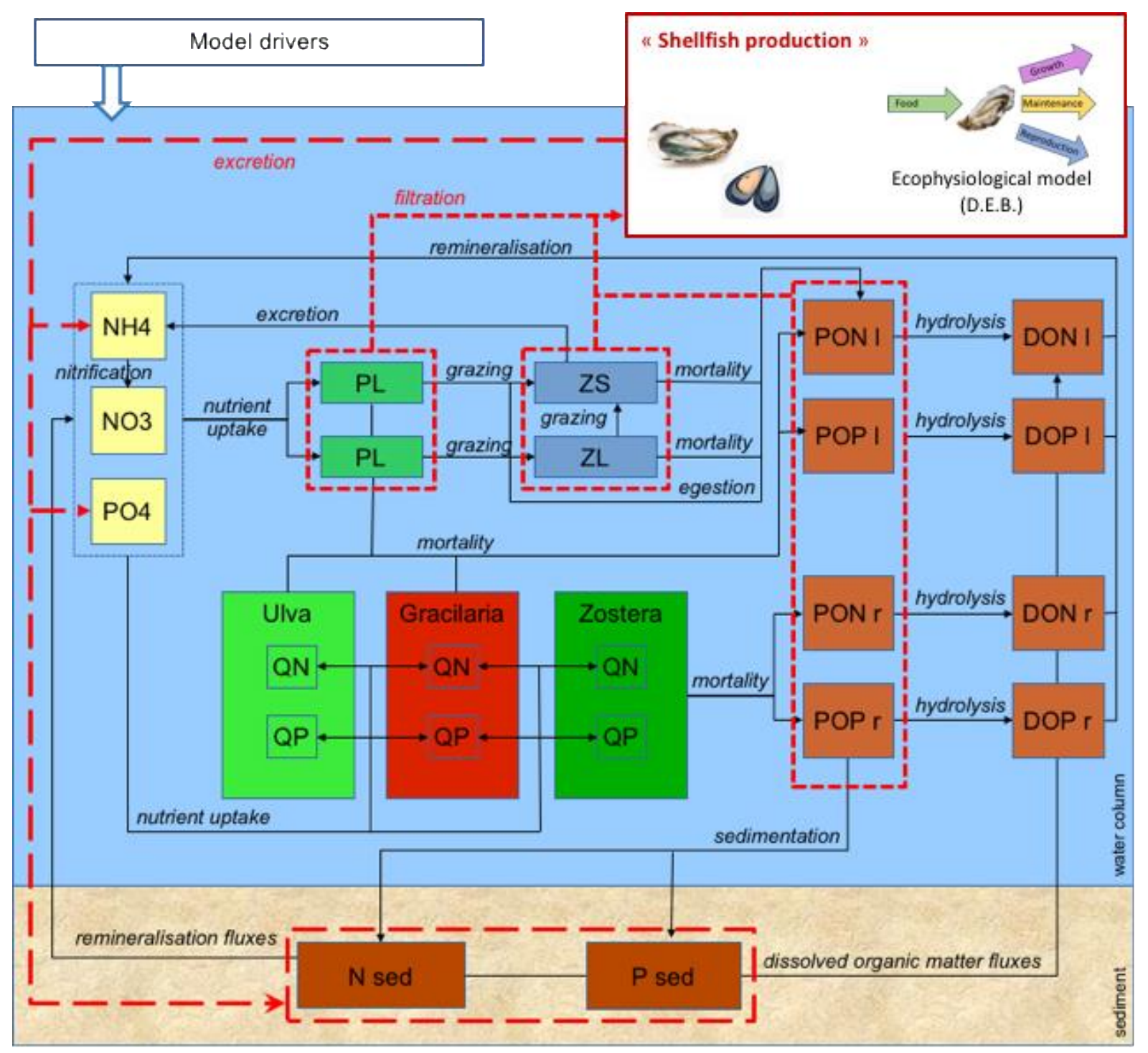

Figure 2. Conceptual scheme of the GAMELag-Conch model representing biological compartments (boxes) and processes (black arrows) within the water column (blue area) and sediment (brown area).

The oyster ecophysiological model is linked to the biogeochemical cycles (red boxes) through filtration and excretion processes (red arrows).

In order to model the growth of an average oyster individual in the shellfish production areas of the Thau Lagoon, a coupling of the GAMELag and DEB oyster model was carried out to form "GAMELag-Conch" model. It involves the integration of the DEB model into the biogeochemical model. The dynamic energy budget of $C$. gigas model is based on the DEB 
theory (Kooijman, 2009) and adapted to the Pacific oyster in the Atlantic under various versions, 3 state variables (Pouvreau et al., 2006) or 4 state variables (Bernard et al., 2011b). The dynamics in time of the different energy fluxes are described by a system of differential equations (see suppl. Mat. Tables S1) and associated processes (Pouvreau et al., 2006; Bernard et al., 2011b;). Within the frame of this work, the model was adapted and parameterised for the Thau lagoon with additional parameters related to rearing schemes (see suppl. Mat., Table S2).

The DEB model operates on energy flows (in joules) allocated to different functions within the individual (reserve, maintenance, growth and reproduction). Among these energy costs, some imply a dissipation of energy, which must be translated into excretion of matter to maintain steady mass balances within the GAMELag-Conch model. The oyster food resource in terms of nitrogen and phosphorus $\left(\mathrm{X}_{\mathrm{N}}\right.$ and $\left.\mathrm{X}_{\mathrm{P}}\right)$ is assumed to be a mix of various available particles in the water column (e.g. state variables of the biogeochemical model) and is defined as:

$$
X_{N}=\alpha_{P S} P S+\alpha_{P L} P L+\alpha_{Z S} Z S+\alpha_{Z L} Z L+\alpha_{P O N} P O N
$$

and

$$
X_{P}=\frac{\alpha_{P S} P S+\alpha_{P L} P L}{N P_{\text {phyto }}}+\frac{\alpha_{Z S} Z S+\alpha_{Z L} Z L}{N P_{\text {zoo }}}+\alpha_{P O P} P O P
$$

where PS, PL, ZS and ZL are small and large phytoplankton and small and large zooplankton and PON the sum of labile and refractory particulate organic nitrogen. Each of these food resources is weighted by a preference coefficient $\alpha_{i}$ with $i=\mathrm{PS}, \mathrm{PL}, \mathrm{ZS}, \mathrm{ZL}, \mathrm{PON}$ or POP. The oyster food resource is expressed in phosphorus using $\mathrm{N}$ to $\mathrm{P}$ stoichiometry of phytoplankton and zooplankton, $\left(\mathrm{NP}_{\text {phyto }}\right.$ and $\left.\mathrm{NP}_{\text {zoo }}\right)$, whereas $\mathrm{POP}$ is the sum of labile and refractory particulate organic phosphorus. Hence, the stoichiometry of food resources is expressed as

$$
N P_{X}=\frac{X_{N}}{X_{P}} \quad \text { Eq. } 3
$$


The food resource and dissipated DEB energy fluxes were translated respectively from mmol $\mathrm{N}$ (or P) to Joules and from Joules to mmol N (or P) using conversion factors (see suppl. Mat., Table S2).

In the DEB model, some of the available energy is lost. First, there is the amount of material ingested but not assimilated by the oyster, which is expressed in the DEB model by the excretion of feces and pseudo-feces (joules per unit of time). This part of the non-assimilated food either reached the sea bed to fuel sediment stock of $\mathrm{N}$ and $\mathrm{P}$ or was remineralised into inorganic nitrogen and phosphorus in the water column. Once assimilated, the energy is allocated into the compartments of the DEB model (structures, reserves and reproduction). In order to maintain balanced stoichiometry in the DEB model, excretion is required and is simulated according to the stoichiometry of the ingested material. Thus, the ratio $\mathrm{N}: \mathrm{P}$ of the resource $(\mathrm{NP} x)$ is compared to the ratio $\mathrm{N}: \mathrm{P}$ of the oyster $\left(\mathrm{NP}_{\mathrm{O}}\right)$. When this $\mathrm{NP}_{\mathrm{X}}$ is greater than the $\mathrm{NP}_{\mathrm{O}}$, the regeneration of material is in the form of ammonium in the model. On the contrary, when the $\mathrm{NP}_{\mathrm{X}}$ is lower than the $\mathrm{NP}_{\mathrm{O}}$, the regeneration was assumed to be in the form of orthophosphate. In this way, even if the stoichiometry of the resource is variable, the individual rejects a quantity of $\mathrm{N}$ or $\mathrm{P}$ to maintain a balanced stoichiometry. This system of regeneration of post-assimilation material provides available mineral forms of $\mathrm{N}$ and $\mathrm{P}$ in the water column. The maintenance costs $\left(\dot{\mathrm{p}}_{M}+\dot{\mathrm{p}}_{J}\right)(\mathrm{Eq} .4)$, growth costs $\left(\dot{\mathrm{p}}_{G}\left(\mathrm{E}_{G}-\mathrm{d}_{V} \times\right.\right.$ $\left.\left.\mu_{V}\right) / \mathrm{E}_{G}\right)\left(\right.$ Eq. 5) and gamete production costs $\left(\dot{\mathrm{p}}_{G}\left(\mathrm{E}_{\mathrm{GGo}}-\mathrm{d}_{\mathrm{Go}} \times \mu_{\mathrm{Go}}\right) / \mathrm{E}_{\mathrm{GGo}}\right)(\mathrm{Eq.} 6)$ were also added to the amounts of regenerated matter as they correspond to dissipated energy (see suppl. Mat., Table S3). In the GAMELag-Conch model, these energy costs were converted into $\mathrm{NH}_{4}{ }^{+}$or $\mathrm{PO}_{4}{ }^{3-}$ with conversion factors $\mathrm{C}_{\text {oyster }}$ and $\mu_{\mathrm{EN}}$ (energy yield of reserves). These conversion factors are based on the available data on the chemical potential of the different compartments of the oyster (Add-my-pet portal:

https://www.bio.vu.nl/thb/deb/deblab/add_my_pet/). Thus, the chemical potential of the food, 
once converted to $\mathrm{J} \mathrm{mmol}^{-1} \mathrm{~N}$, gives a conversion factor, $\mathrm{C}_{\text {oyster, }}$ of $3250 \mathrm{~J} \mathrm{mmol}^{-1} \mathrm{~N}$. The $\mathrm{C}_{\text {oyster }}$ conversion factor affects energy related to ingested but non-assimilated matter (feces and pseudo-feces) and the energy related to predation on the different compartments composing oyster food (ie, small and large phytoplankton, small and large zooplankton and particulate organic matter). The second conversion factor, $\mu_{\mathrm{EN}}$, is obtained by deriving the chemical potential of bivalve reserves with the nitrogen (or phosphorus) content of the organic matter that makes up these reserves. The factor thus obtained is $3667 \mathrm{~J} \mathrm{mmol}^{-1} \mathrm{~N}$. In general, these conversion factors vary between 2400 and $3700 \mathrm{~J} \mathrm{mmol}^{-1} \mathrm{~N}$ depending on whether food, structure or reserves are considered as N or P content (Platt and Irwin, 1973; Grangeré et al., 2009).

\subsection{Oyster seeding scheme in the model}

Seeding scheme, as the introduction in farming structures of spats and oysters, is rather complex in the Thau lagoon and mainly depends on environmental conditions, contamination risks time frame or market dynamics. Two main periods for seeding were extracted from the monograph results (Cepralmar, 2016) indicating that, according to growth durations, most spats (6 to $8 \mathrm{~mm}$ ) were mainly reared on lanterns or pearl nets and introduced between July and August (47\% reared over the summer) for a period of 6 to 8 months. In addition, this study indicated that oysters ( 15 to $20 \mathrm{~mm}$ ) were introduced within the early months of the year (53\% in January and February) for a duration of 12 to 14 months to reach marketablesize oyster. Therefore, in order to simplify this seeding time schedule for the GAMELagConch model, we assumed a common seeding scheme where oysters were introduced on the first of February and harvested in mid-December. Regarding to spat seeding, the first of July was used in the model to start growth of spats for a duration of 7 months. In February, remaining spats from year $n$ were then used to seed oysters in year $n+1$. The total abundances 
were $532.110^{6}$ and $235.710^{6}$ individuals for spats and oysters respectively for the entire farming zone (box $4+$ box 5 , Figure 1). Mortality rates were also extracted from the monograph with values of $38.2 \%\left(10.5 \times 10^{-4} \mathrm{~d}^{-1}\right)$ during the pre-growing phase and $32.5 \%$ $\left(8.910^{-4} \mathrm{~d}^{-1}\right)$ during the growing phase (Cepralmar, 2016). Seeding densities were then used to simulate stocking densities over the growing period as follows:

$\frac{\text { doyster }}{d t}=$ Seeding $_{\text {oyster }}-$ Oyster $\times$ mortality $_{\text {Oyster }} \quad$ Eq. 7

And

$\frac{d \text { Spat }}{d t}=$ Seeding $_{\text {Spat }}-$ Spat $\times$ mortality $_{\text {Spat }} \quad$ Eq. 8

Where Seeding oyster $_{\text {and Seeding }}$ spat are densities of oysters and spats introduced as described above. The number of individuals introduced was extracted from the monograph (Cepralmar, 2016) and extrapolated to the farming zones with data from local authorities (DDTM, 2014), which represented an average exploitation of $70 \%$ of growing structures. Length (L) and dry flesh matter (DFM) were calculated at harvest for each simulated year. Annual oyster production was estimated from total weight (derived from DFM, equation 16, Table S1 in suppl. Material) and the number of living individuals simulated at harvest. Oyster condition index (CI, \%) was estimated from model outputs by using the ratio of DFM (g) over Length $(\mathrm{cm})$.

\subsection{Reference simulation}

The baseline simulation (e.g. "Reference", scenario $\mathrm{n}^{\circ} 1$, Table 1 ) used in this study represented the current conditions of the Thau lagoon functioning. This baseline simulation was used to evaluate model skills (see section 2.5). This simulation covered the period from 2014 to 2016 and was carried out with the hydro-meteorological conditions of these three years including precipitation, contributions of the natural catchment and contributions from 
WWTP, based on the data of self-monitoring recorded at the entrance of the WWTP (data from SMBT).

Table 1. Summary of scenarios tested with reference simulation, watershed nutrient inputs and shellfish densities described according to their characteristics.

\begin{tabular}{|c|c|c|c|c|}
\hline $\begin{array}{l}\text { Type of } \\
\text { scenario }\end{array}$ & $\begin{array}{l}\text { Scenario } \\
\text { number }\end{array}$ & Characteristic & $\begin{array}{c}\text { Observation - management } \\
\text { interest }\end{array}$ & $\begin{array}{c}\text { Name of } \\
\text { scenario in } \\
\text { figures }\end{array}$ \\
\hline Reference & 1 & $\begin{array}{l}\text { Current stocking densities, WWTP outputs } \\
\text { estimated from current average abatements }\end{array}$ & $\begin{array}{l}\text { Use as a standard for } \\
\text { comparing scenarios }\end{array}$ & Ref \\
\hline \multirow[t]{4}{*}{$\begin{array}{l}\text { Watershed } \\
\text { inputs }\end{array}$} & 2 & $\begin{array}{l}\text { Maximum yield on N\& P for all WWTP } \\
\qquad(\geq 90 \% \text { on both N \& P) }\end{array}$ & $\begin{array}{l}\text { Correspond to the scheme for } \\
\text { water management (SAGE) }\end{array}$ & Max. yield \\
\hline & 3 & $\begin{array}{l}\text { Normal yield on N \& P for all WWTP } \\
\qquad(75 \% \mathrm{~N}, 60 \% \mathrm{P})\end{array}$ & $\begin{array}{c}\text { Classification off } « \text { sensitive } \\
\text { zone » to eutrophication }\end{array}$ & Nal yield \\
\hline & 4 & $\begin{array}{l}\text { Projection of an increase in the number of } \\
\text { inhabitants in the territory }\end{array}$ & $\begin{array}{l}\text { Correspond to the } \\
\text { comprehensive territorial } \\
\text { occupation scheme (SCOT) } \\
\text { predicting a } 23 \% \text { increase of } \\
\text { the population in the Thau } \\
\text { watershed by } 2030\end{array}$ & SCOT \\
\hline & 5 & $\begin{array}{l}\text { Partial release of water and nutrients from the } \\
\text { Sète WWTP into the lagoon }\end{array}$ & $\begin{array}{l}\text { Operating strategy of Sète } \\
\text { WWTP }\end{array}$ & Sète \\
\hline $\begin{array}{l}\text { Shellfish } \\
\text { farming }\end{array}$ & 6 & $\begin{array}{c}\text { Seeding to the maximum of the growing } \\
\text { structure capacity according to the « structure } \\
\text { scheme (DDTM) }\end{array}$ & $\begin{array}{l}\text { Evaluation of the effect of the } \\
\text { maximum capacity of } \\
\text { breeding structures on the } \\
\text { lagoon ecosystem and oyster } \\
\text { production and performances }\end{array}$ & Max. dens. \\
\hline
\end{tabular}

Hydrological conditions of the simulated years were contrasted in terms of total rainfall and associated trophic contributions. The year 2015 , defined as a dry year (-255 $\mathrm{mm}$ compared to 1970-2016 average), showed low natural hydrological contributions with inputs of $0.77 \mathrm{t}$ of $\mathrm{P}$ and $12.7 \mathrm{t}$ of $\mathrm{N}$, whereas the years 2014 and 2016, with more intense rainfall events $(+70 \mathrm{~mm}$ and $-55 \mathrm{~mm}$ compared to $1970-2016$ average), brought natural nutrient loadings to a respective estimate of 5 and $5.6 \mathrm{t}$ of $\mathrm{P}$ and $86.6 \mathrm{t}$ and $98 \mathrm{t}$ of $\mathrm{N}$. During wet years, anthropogenic inputs from WWTP amounted for $18 \%$ of N loading against $55 \%$ for P inputs. Total inputs from the watershed (natural and anthropogenic) reached 109.2, 39.4 and 113.8 tons of $\mathrm{N}$ and 10.1, 6.1 and 10.2 $\mathrm{t}$ of $\mathrm{P}$ for the three simulated years. For the year 2015, WWTP discharges constituted the main source of $\mathrm{N}(62 \%)$ and $\mathrm{P}(90 \%)$ inputs, whereas for 
the wet years 2014 and 2016, WWTP inputs accounted for up to $20 \%$ of total nutrient loadings. The initialization of the biological compartments takes into account the most recent observations in order to get as close as possible to the current conditions in the simulations. Concerning the initialization of shellfish culture, data from the Cépralmar monograph (Cépralmar, 2016) were used for livestock densities in the Bouzigues and Mèze-Marseillan areas (see section Oyster seeding scheme in the model). The extrapolation of these survey results to both production areas was based on the data provided by local authorities (DDTM, 2014) with 2632 tables in concession of which 382 were not active. The estimate of the structures hosting pre-growth (spats) and growth (adults) was conducted using data from the monograph (Cepralmar 2016) extrapolated to the 2250 tables in operation on each of the two areas. This baseline scenario is referred as "Ref" in table 1 (scenario $n^{\circ} 1$, Table 1$)$.

\subsection{Model skills evaluation \& model computation}

The Willmott index of agreement (Willmott, 1981), d, was used to evaluate the performance. This metric is a standardized measure of the degree of model prediction error and varies between 0 and 1 . A value of 1 indicates a perfect match, and 0 indicates no agreement at all. This index of agreement was used to evaluate model skills on salinity, Chl $a$ concentration as well as shell length $(\mathrm{cm})$ and tissue dry weight $(\mathrm{g})$ of cultured oysters. Available observations for these variables were compared to simulations for the two shellfish farming zones (Figure 1, box 4 and 5). The GAMELag-Conch model was implemented in R (R Core Team, 2017), using the deSolve package (Soetaert et al., 2010) for differential equation solving (time step: 1 day). 


\subsection{Description of scenarios}

Scenarios of different nutrient inputs and shellfish culture strategies were determined in close interactions with shellfish farmers (Mediterranean shellfish committee, CRCM), managers (the Thau basin organization, SMBT; the Centre for studies of lagoon and maritime activities, CEPRALMAR; the French water agency, AERM\&C; Departmental Direction of Territories and Sea DDTM) and scientists (MARBEC). These scenarios were built on realistic management hypotheses, established during participative meetings and are based on two main axes: 1) scenarios related to trophic contributions from the watershed and associated management measures and 2) scenarios related to shellfish production and they are summarized in Table 1.

The anthropogenic contributions of the watershed were tested according to different scenarios corresponding to different management hypotheses around the watershed of Thau (Scenario 2 to 5, Table 1). The yields of the WWTPs are constrained by the environment that receives the discharges and come within the context of the Regional Plan for Water Management (SDAGE Rhône-Méditerranée) and the local Water Management Scheme (SAGE) applied to the Thau lagoon territory. When these receiving water bodies carry a risk of eutrophication, they are classified as sensitive to eutrophication according to European regulation (EC, 1991). In the context of "sensitive zones", the European legislation (EC, 1991) requires WWTP to treat at least $80 \%$ of phosphorus and 70 to $80 \%$ of nitrogen for cities with more than 10000 inhabitant equivalents (IE). For smaller municipalities, these obligations vary and may be higher depending on the case. Thau lagoon was classified as a "sensitive zone" in 2004 according to European recommendations (EC, 2004). On these provisions, it was concluded to test initially two scenarios declining these treatments of WWTP to: 1) maximum yield (scenario 2: Max. yield) with abatements greater than 90\% for nitrogen and phosphorus; 2) normal yield (scenario 3: Nal yield) corresponding to reductions of 75\% and 60\% respectively 
for nitrogen and phosphorus. It should be noted that only the Mèze lagoon-based treatment plant currently offers yields comparable to the high abatements required by the "sensitive zone" classification (> 90\%).

In direct relation with the environmental management constraints, the territorial occupation scheme (SCOT) and, in particular, the demographic projections of this SCOT, were evaluated in this study. Indeed, an increase in population (estimated at $23 \%$ at 2030 horizon) directly leads to increased WWTP effluents (wastewater discharges) and, consequently, recommendations to anticipate these evolutions must be incorporated into a management policy of the territory. This scenario (Scenario 4, "SCOT" Table 1) aimed at estimating the impact of the population increase on the Thau catchment area by 2030 in terms of nitrogen and phosphorus inputs to the lagoon, as well as its impact on ecological status and shellfish cultures in the Thau lagoon. Current yields of WWTPs were then applied to these estimated quantities of nitrogen and phosphorus to provide quantities entering the lagoon.

The following scenario (scenario 5; "Sète", Table 1) corresponded to potential management leverage for freshwater and nutrient inputs $(\mathrm{N} \& \mathrm{P})$ to the lagoon through an operating strategy of the Sète WWTP. This scenario addressed the question of the evaluation of the impact of discharges in the Sète channels and hence in the lagoon, in anticipation of important modernization works on the WWTP. The Sète WWTP currently has its outfall in the sea but could release discharges to the Sète channels in case of heavy rains. This scenario examined the effect of an additional 69.5, 72.9 and 84.7 tons of nitrogen in 2014, 2015 and 2016 respectively. In terms of phosphorus, additional quantities were estimated at 3.7, 3.1 and 3.6 tons for the same years respectively.

The scenario of different oyster stocking densities tested in this study corresponded to seeding conditions for which all the growing structures would be filled with oysters at the maximum densities allowed by the structure scheme (DDTM, 2014). In comparison to reference seeding 
conditions (see section Oyster seeding scheme in the model), abundances were increased by a factor 2 for spats (e.g. $50110^{6}$ and $54610^{6}$ individuals for box 4 (Bouzigues) and box 5 (Mèze-Marseillan), respectively) and by a factor 1.3 for oysters (e.g. $158.710^{6}$ and $129.910^{6}$ individuals for box 4 and box 5, respectively).

\subsection{Data treatment and scenario realization}

Prior to the simulations of these different scenarios, a first step was the WWTP data processing to force the GAMELag-Conch model. Work to recover volumes and concentrations of global nitrogen (NGL) and global phosphorus (PGL) at the inlets of the WWTPs was performed based on data from SANDRE (portal:

http://www.sandre.eaufrance.fr). These data were used to establish: 1) yield matrices, for each WWTP located on the Thau watershed, and 2) matrices of fractions of the different forms of nitrogen and phosphorus for each of the WWTP, to allow the transformation of total nitrogen and total phosphorus after treatment into their different inorganic and organic fractions necessary to force the model.

In a first step, the input data of WWTP undergoes a reduction corresponding to the scenario tested (see abatements, Table 1) and in a second step, the output concentrations thus estimated are fractionated according to the different forms of nitrogen and phosphorus for the corresponding WWTP. This procedure allowed for multiple different yield matrices (or input augmentations as per SCOT projections) applied to the same starting NGL and PGL datasets. This method was applied for all scenarios with three matrices of yields covering current treatment, maximum treatment and normal treatment (see sections on Reference and scenarios description). 


\subsection{Carrying capacity evaluation}

As mentioned in the introduction, the targeted carrying capacity lies in the equilibrium between an optimised harvest without negative effects on ecological functioning. The dame index and phytoplankton depletion index were then used where the former provides a bulk information on ecosystem functioning and allows comparison between different ecosystems. Whereas the depletion index linked more finely cultured bivalves to its resource.

\subsubsection{Dame index}

The Dame index was calculated from the characteristic times of the lagoon (Dame and Prins., 1998). These characteristic times included: i) the lagoon renewal time (RT: time required to renew the entire lagoon volume) which is a hydrodynamic feature, ii) the phytoplankton renewal time (PPT: equivalent to the ratio of the average phytoplankton biomass to average gross primary production); and finally, iii) the clearance time (CT: time required for the total stock of shellfish to filter the lagoon volume).

The renewal time (RT) was calculated for the whole lagoon using the volumes entering the lagoon by the Sète channel:

$R T=\frac{V_{\text {lagune }}}{\overline{V_{l n}}} \quad$ Eq. 9

Where $V_{\text {lagune }}$ and $\overline{V_{l n}}$ were the volumes of the lagoon $\left(\mathrm{m}^{3}\right)$ and mean annual incoming volume $\left(\mathrm{m}^{3} \mathrm{~d}^{-1}\right)$, respectively. This formulation gave renewal times of $48.6,48.4$ and 48.8 days for the years 2014, 2015 and 2016 respectively. These RT values were in agreement with the field observations reported by Fiandrino et al. (2012) where RT $\sim 50$ days.

The phytoplankton renewal time (PPT) was obtained by the ratio of the annual mean phytoplankton biomass (estimated from the $\mathrm{Chl} a$ concentration expressed in mmol N m${ }^{-3}$ ) on the mean daily gross primary production (estimated from the phytoplankton growth calculated by the model and expressed in mmol $\mathrm{N} \mathrm{m}^{-3} \mathrm{~d}^{-1}$ ). 
The clearance time (CT), time required for cultured oysters to filter the volume of the lagoon, was calculated taking into account the oyster filtration rate according to the formulation of Bougrier et al. (1995):

Filtration rate $=4,825-\left(0,013 \times\left(T_{{ }^{\circ} C}-18,954\right)^{2}\right) \times D F M^{0,439}$ Eq. 10

Where $\mathrm{T}^{\circ} \mathrm{C}$ was the temperature in degrees Celsius and DFM the dry weight $(\mathrm{g})$ at harvest. The filtration rate was expressed in $\mathrm{L} \mathrm{ind}^{-1} \mathrm{~h}^{-1}$. The clearance time CT was expressed by comparing the filtered volume with the average volume of the lagoon:

Clearance time $=\frac{\text { Vol }_{\text {lagoon }}}{\text { filtration rate } \times \text { nb of individuals } \times 24 / 1000} \quad$ Eq. 11

where the filtration rate was extrapolated to the number of cultured individuals for a day and expressed in $\mathrm{m}^{3} \mathrm{~d}^{-1}$ and $\operatorname{Vol}_{\text {lagoon }}\left(\mathrm{m}^{3}\right)$ to give a clearance time in days.

All these characteristic times were expressed in days and their ratios (CT:RT and CT:PPT) potentially inform on the capacity of the lagoon to support or not a sustainable shellfish production. The CT:RT ratio indicated whether filter feeders and its resources were controlled by exchanges with the sea or by internal (including inputs from the watershed) availability of nutrients. The CT:PPT ratio expressed directly the link between the resource and the shellfish culture, where a ratio of 1 would indicate that all phytoplankton primary production was consumed by filter feeders in culture and would therefore be a critical value.

\subsubsection{Lagoon-scale phytoplankton depletion index}

At the scale of the lagoon area, a phytoplankton depletion index (Filgueira et al., 2014a) was calculated to determine the impact of shellfish farming on its main resource. This index compared the average phytoplankton biomass in farming areas (box 4 and 5, Figure 1) with the phytoplankton biomass produced outside these zones (off-table: boxes 1, 2 and 3; Figure 1). Negative values indicated a depletion in nutritive resource, whereas positive values indicated sufficient resource for the growth of bivalves. 
Lagoon - scale depletion index $=\frac{\overline{[C h l a]}_{\text {farms }}}{{\overline{[C h l a]_{\text {off-table }}}}_{\text {La }}} \times 100-100$

Eq. 12

This formula compared the daily average Chl $a$ concentration of all shellfish growing areas (box 4 and 5, Figure 1) with the daily average Chl $a$ concentration for all off-table areas (boxes 1, 2 and 3, Figure 1).

This index may be gauged against the natural variability of the phytoplankton biomass to evaluate the sustainability of the shellfish farming activity (Grant and Filgueira, 2011). This lagoon-scale depletion index is asymmetrical and a value of $-100 \%$ indicates a complete depletion, whereas enrichment has no upper limit. For this reason, the median annual values of this index were preferred to mean values and were used to compare the scenarios.

\subsection{Ecological indicators and ecological status}

The compartments of the model relative to the dissolved organic and inorganic matter were used to estimate summer nutrient concentrations. $90^{\text {th }}$ percentiles $(\mathrm{p} 90)$ were calculated from the 92 daily values obtained from June $1^{\text {st }}$ to August $31^{\text {st }}$ for each simulated year, of dissolved inorganic nitrogen $\left(\mathrm{DIN}=\mathrm{NO}_{3}{ }^{-}+\mathrm{NH}_{4}{ }^{+}\right)$, dissolved inorganic phosphorus (DIP), total nitrogen (TN: dissolved and particulate inorganic and organic nitrogen as well as the two "small" and "large" phytoplankton compartments) and total phosphorus (TP: inorganic phosphorus and dissolved and particulate organic and phytoplankton compartments expressed as phosphorus using the Redfield (1963) N:P ratio of 16). These four variables DIN, DIP, TN and TP, represented estimates of the WFD indicators measured for the diagnosis of the ecological status of lagoon water bodies (Derolez et al., 2013). These simulated indicators were used to compare the "Reference" scenario with actual observations and the influence of the different scenarios tested on the ecological status. The model also estimated Chlorophyll $a$ concentration in the water column using the "small" and "large" phytoplankton variables. These two state variables were expressed in $\mathrm{mmol} \mathrm{N} \mathrm{m}^{-3}$ in the model and converted to $\mu \mathrm{g}$ 
Chl $a \mathrm{l}^{-1}$ using a conversion factor of 1 (Parsons et al., 1961). The summer averages obtained from the simulations were used as an indicator of the phytoplankton biomass as in the WFD diagnosis. Finally, the TN to TP ratio was used as an indicator of nitrogen and phosphorus balance within the system.

\subsection{Statistical analyses}

Data did not fulfilled tests for both normality and homosedasticity and non-parametric, Kruskal-Wallis, was therefore used for statistical analysis. Correlations were determined following Spearmann correlation coefficient, $\rho$. Statistical analyses were considered significant with $\mathrm{p}$-value $<0.01$. Principal component analysis (PCA) was performed on model outputs presented in this work. All statistical analyses were performed using the R software (R Core Team, 2017).

\section{Results}

\subsection{Model skills}

Model skills evaluation was based on model outputs of the "Reference" scenario representing current situation. The GAMELag-Conch model satisfactorily simulated observations of salinity (Figure 3-A) for both shellfish farming zones with a Willmott index "d" of 0.96 (linear regression $r^{2}=0.91$ ). This agreement between observed and simulated values prevailed the good representation of the lagoon hydrodynamics when described by 3 physical boxes (see "Carrying capacity model" description").

Similar to salinity, model outputs were correctly correlated with the observed length (Figure 3-C) and dry weight (Figure 3-D) of oysters, with Willmott index of $0.69\left(\mathrm{r}^{2}=0.77\right)$ and 0.76 $\left(r^{2}=0.76\right)$ respectively. 

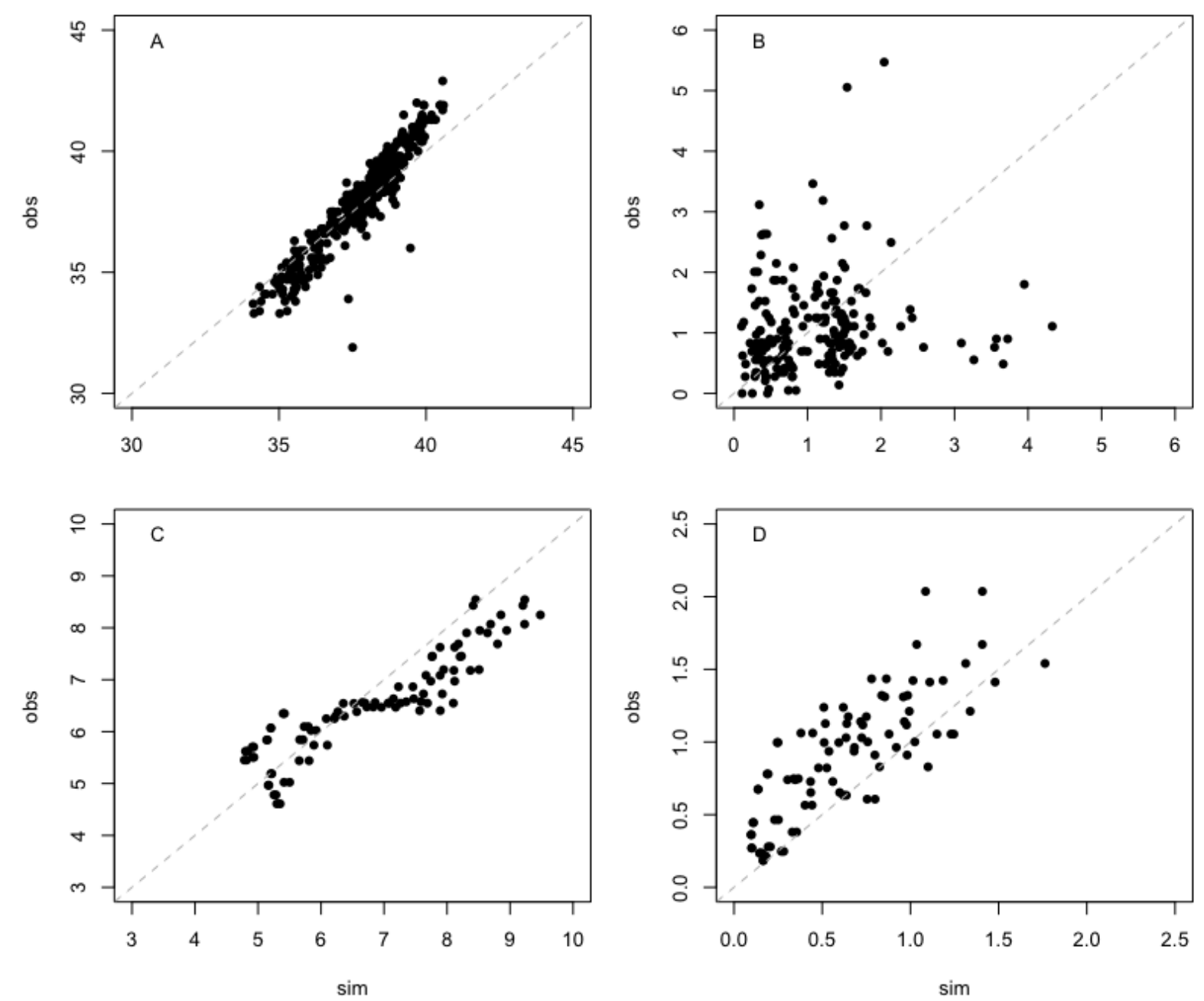

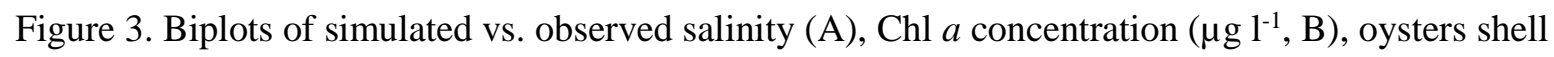
length $\mathrm{L}(\mathrm{cm}, \mathrm{C})$ and oyster dry weight $(\mathrm{g}, \mathrm{D})$ extracted from model outputs within the two shellfish farming zones (box 4 and 5).

A poorer Willmott index was found for the Chl $a$ variable at $\mathrm{d}=0.46\left(\mathrm{r}^{2}=0.03\right)$. The comparison of observations against simulations indicated that simulated $\mathrm{Chl} a$ concentrations were within the range of observations for concentrations lower than $2.5 \mu \mathrm{g} \mathrm{Chl} a . \mathrm{L}^{-1}$. However, the model could not capture the timing of extreme values (peaks), which explained the mismatch on Figure 3-B for high Chl $a$ concentrations. 
For the three simulated years and all the scenarios, annual nutrient inputs varied from 25.5 to 198.6 tons of nitrogen and from 1.8 to 13.8 tons of phosphorus (Table 2). These ranges included lower and higher values of nutrient inputs than that of the Reference scenario (39.4 to 111.5 t of $\mathrm{N}$ and 6.1 to $10.2 \mathrm{t}$ of $\mathrm{P}$, Table 2). Results presented in Fig. 4 and Table 2 highlighted the significant variability of oyster performances (weight and production) according to years and scenarios of nutrient inputs. The variability of oyster production as well as total weight of oyster, was mainly controlled by the hydrometeorology, with oyster production being 1.8-2.3 times higher during rainy years than dry years whatever the tested scenario (Table 2). Total weight of oysters at harvest varied between 36.6 to $100.5 \mathrm{~g}$ (Table 2) according to scenarios and simulated years. Similar to production, total weight was significantly higher in wet years than dry years (Kruskal-Wallis, $\mathrm{p}<0.05)$, although no significant differences were found between scenarios. In comparison to the current situation (Reference), higher oyster productions were simulated with normal waste water treatment plant efficiency (Normal Yield: \75\% N, \60\% P) with an additional 1700 t produced during dry years corresponding to an increase in production of $25 \%$. This increase was less important during wet years (940-1200 t, +5-7\%). By contrast, maximum WWTP efficiency (Max yield $\searrow 90 \% \mathrm{~N} \& \mathrm{P}$ ) induced a mean decrease of $1598 \mathrm{t}$, corresponding to a decrease of $12 \%$ in comparison with mean reference production. The foreseen increase in population (SCOT scenario) induced a mean increase in oyster production of 5\%. Finally, in the Séte scenario, oyster production was not enhanced and recorded $875 \mathrm{t}$ less than reference production (Table 2), while nitrogen and phosphorus inputs were significantly higher than reference (1.8-2.8 times more $\mathrm{N}$ and 1.3-1.5 more $\mathrm{P}$ ). Scenario of oyster stocking density to its authorized maximum (by the French regulation body) triggered a mean increase of oyster productions by $7 \%$ at the expenses of thinner oysters with a lower condition index. 
Table 2. Summary of simulations inputs and outputs for the three years (2014-2015-2016) and the six scenarios tested.

\begin{tabular}{|c|c|c|c|c|c|c|c|c|c|c|c|c|}
\hline & $\begin{array}{l}\text { Annual N } \\
\text { inputs (t) }\end{array}$ & $\begin{array}{l}\text { Annual P } \\
\text { inputs (t) }\end{array}$ & $\begin{array}{l}\text { Inputs N:P } \\
\text { molar } \\
\text { ratio }\end{array}$ & $\begin{array}{c}\text { Production } \\
\text { at harvest } \\
\text { (tons) }\end{array}$ & $\begin{array}{l}\text { Length } \\
\text { at } \\
\text { harvest } \\
(\mathrm{cm})\end{array}$ & $\begin{array}{l}\text { Total weight } \\
\text { at harvest } \\
\text { (g) }\end{array}$ & $\begin{array}{c}\text { Condition } \\
\text { index at } \\
\text { harvest } \\
(\%)\end{array}$ & $\begin{array}{c}\text { Ecological status a } \\
\text { [NID-PID-TN-TP-CHLA-TN:TP] } \\
\text { Summer - P90 - }(\mu \mathrm{M})\end{array}$ & $\begin{array}{c}\text { RT } \\
\text { (days) }\end{array}$ & $\begin{array}{c}\text { CT } \\
\text { (days) }\end{array}$ & $\begin{array}{l}\text { PPT } \\
\text { (days) }\end{array}$ & $\begin{array}{c}\text { Median } \\
\text { lagoon- } \\
\text { scale } \\
\text { depletion } \\
\text { index }(\%)\end{array}$ \\
\hline \multicolumn{13}{|l|}{ Reference } \\
\hline 2014 & 109.2 & 10.1 & 23.9 & 16977 & 9.5 & 93.7 & 17.5 & {$[0.31-0.50-16.00-1.29-1.68-13.52]$} & 48.6 & 17.4 & 6.3 & -14.1 \\
\hline 2015 & 39.4 & 6.1 & 14.3 & 7896 & 8.0 & 43.6 & 9.7 & [0.49-0.45-20.35-1.39-3.57-18.52] & 48.4 & 20.1 & 7.1 & -12.8 \\
\hline 2016 & 113.8 & 10.2 & 24.7 & 12208 & 8.8 & 67.4 & 13.6 & [0.34-0.46-18.56-1.35-3.43-16.65] & 48.8 & 18.2 & 7.4 & -14.0 \\
\hline Mean $\pm s d$ & $87.5 \pm 41.7$ & $8.8 \pm 2.3$ & $21.0 \pm 5.8$ & $12360 \pm 4542$ & $8.8 \pm 0.8$ & $68.2 \pm 25.1$ & $13.6 \pm 3.9$ & [0.38-0.47-18.30-1.34-2.89-16.23] & $48.6 \pm 0.2$ & $18.6 \pm 1.4$ & $6.9 . \pm 0.6$ & $-13.6 \pm 0.7$ \\
\hline \multicolumn{13}{|l|}{ Max. yield } \\
\hline 2014 & 93.9 & 5.8 & 35.7 & 15606 & 9.4 & 86.2 & 16.3 & [0.31-0.41-15.64-1.19-1.70-14.56] & 48.6 & 17.3 & 6.0 & -14.2 \\
\hline 2015 & 25.5 & 2.0 & 28.8 & 6669 & 7.5 & 36.8 & 8.7 & [0.50-0.48-21.15-1.48-3.90-18.88] & 48.4 & 19.8 & 7.2 & -12.4 \\
\hline 2016 & 100.2 & 6.3 & 35.5 & 10011 & 8.3 & 55.2 & 11.8 & [0.34-0.47-19.18-1.40-3.62-17.82] & 48.8 & 18.0 & 7.4 & -13.7 \\
\hline Mean $\pm s d$ & $73.2 \pm 41.4$ & $4.7 \pm 2.4$ & $33.3 \pm 3.9$ & $10762 \pm 4515$ & $8.4 \pm 0.9$ & $59.4 \pm 25.0$ & $12.3 \pm 3.8$ & [0.38-0.46-18.65-1.35-3.07-17.09] & $48.6 \pm 0.2$ & 18.4. \pm 1.3 & $6.9 \pm 0.7$ & $-13.4 \pm 0.9$ \\
\hline \multicolumn{13}{|l|}{ Normal yield } \\
\hline 2014 & 118.6 & 12.3 & 21.4 & 18194 & 9.6 & 100.5 & 18.7 & [0.31-0.54-16.27-1.35-1.68-13.19] & 48.6 & 17.4 & 6.6 & -14.0 \\
\hline 2015 & 46.4 & 8.1 & 12.7 & 9838 & 8.4 & 54.3 & 11.6 & [0.49-0.40-19.43-1.30-3.14-18.59] & 48.4 & 20.6 & 7.1 & -13.3 \\
\hline 2016 & 20.8 & 12.2 & 22.0 & 13909 & 9.2 & 76.8 & 14.9 & {$[0.32-0.42-17.73-1.27-3.15-16.65]$} & 48.8 & 18.4 & 7.5 & -14.2 \\
\hline Mean $\pm s d$ & $95.3 \pm 42.3$ & $10.8 \pm 2.4$ & $18.7 \pm 5.2$ & $13981 \pm 4178$ & $9.0 \pm 0.6$ & $77.2 \pm 23.0$ & $15.0 \pm 3.6$ & {$[0.37-0.45-17.81-1.30-2.66-16.14]$} & $48.6 \pm 0.2$ & 18.8. \pm 1.7 & $7.1 \pm 0.5$ & $-13.8 \pm 0.5$ \\
\hline \multicolumn{13}{|l|}{ SCOT } \\
\hline 2014 & 114.8 & 11.2 & 22.6 & 17894 & 9.6 & 98.8 & 18.4 & {$[0.31-0.52-16.14-1.32-1.67-13.32]$} & 48.6 & 17.4 & 6.4 & -14.0 \\
\hline 2015 & 44.6 & 7.2 & 13.7 & 8610 & 8.2 & 47.5 & 10.3 & [0.50-0.43-19.97-1.35-3.41-18.58] & 48.4 & 20.3 & 7.1 & -13.0 \\
\hline 2016 & 118.9 & 12.2 & 23.3 & 12571 & 9.0 & 69.4 & 13.8 & {$[0.33-0.45-18.35-1.32-3.27-16.61]$} & 48.8 & 18.3 & 7.4 & -14.2 \\
\hline Mean $\pm s d$ & $92.8 \pm 41.7$ & $9.9 \pm 2.3$ & $19.9 \pm 5.4$ & $13025 \pm 4658$ & $8.9 \pm 0.7$ & $71.9 \pm 25.7$ & $14.2 \pm 4.0$ & {$[0.38-0.47-18.15-1.33-2.79-16.17]$} & $48.6 \pm 0.2$ & 18.7. \pm 1.5 & $7.0 \pm 0.5$ & $-13.7 \pm 0.6$ \\
\hline \multicolumn{13}{|l|}{ Sète } \\
\hline 2014 & 178.7 & 13.8 & 28.7 & 16616 & 9.5 & 91.8 & 17.1 & [0.31-0.48-16.84-1.30-1.68-14.13] & 48.7 & 17.3 & 5.9 & -14.2 \\
\hline 2015 & 112.3 & 9.2 & 26.9 & 7184 & 7.8 & 39.7 & 9.1 & [0.51-0.50-22.35-1.52-3.91-18.92] & 48.5 & 20.0 & 6.8 & -12.6 \\
\hline 2016 & 198.6 & 13.6 & 31.7 & 10654 & 8.5 & 58.8 & 12.4 & {$[0.34-0.50-20.71-1.47-3.68-18.14]$} & 48.9 & 18.0 & 7.2 & -13.8 \\
\hline Mean $\pm s d$ & $163.2 \pm 45.2$ & $12.3 \pm 2.6$ & $29.1 \pm 2.4$ & $11485 \pm 4770$ & $8.6 \pm 0.9$ & $63.4 \pm 26.4$ & $12.9 \pm 4.0$ & [0.39-0.49-19.97-1.43-3.09-17.06] & $48.7 \pm 0.2$ & $18.5 \pm 1.3$ & $6.6 \pm 0.6$ & $-13.6 \pm 0.8$ \\
\hline \multicolumn{13}{|l|}{ Max density } \\
\hline 2014 & 109.2 & 10.1 & 23.9 & 18735 & 9.3 & 85.8 & 16.5 & [0.31-0.52-16.00-1.31-1.87-13.46] & 48.6 & 14.1 & 6.0 & -15.1 \\
\hline 2015 & 39.4 & 6.1 & 14.3 & 7976 & 7.8 & 36.6 & 8.3 & [0.44-0.48-20.57-1.44-3.69-18.41] & 48.4 & 16.1 & 6.8 & -13.4 \\
\hline 2016 & 113.8 & 10.2 & 24.7 & 12936 & 8.5 & 59.2 & 12.5 & [0.34-0.54-19.16-1.47-3.56-16.57] & 48.8 & 14.8 & 7.1 & -14.5 \\
\hline Mean $\pm s d$ & $87.5 \pm 41.7$ & $8.8 \pm 2.3$ & $21.0 \pm 5.8$ & $13216 \pm 5385$ & $8.5 \pm 0.7$ & $60.6 \pm 24.7$ & $12.4 \pm 4.1$ & [0.38-0.43-17.00-1.24-2.35-16.07] & $48.6 \pm 0.2$ & $15.0 \pm 1.0$ & $6.7 \pm 0.6$ & $-14.3 \pm 0.9$ \\
\hline
\end{tabular}


To conclude oyster production, the comparison of scenarios showed that only "Sète" $\left(\mathrm{n}^{\circ} 5\right)$ and "Max. yield" $\left(\mathrm{n}^{\circ} 2\right)$ scenarios induced lower oyster production than "Reference" scenario exhibiting a decrease of 8 and $16 \%$ respectively. All other scenarios that involved increased nutrient inputs, "Nal yield" ( $\left.\mathrm{n}^{\circ} 3\right)$ and "SCOT" $\left(\mathrm{n}^{\circ} 4\right)$, presented higher oyster production levels with sensibly higher shell length and total weight (Table 2). On the contrary, if scenario "Max. dens." ( $\left.{ }^{\circ} 6\right)$ rendered higher oyster production than "Reference" scenario, no increase of length or total weight of individuals was apparent. Oyster condition index (CI) was used as a proxy for the health of oysters and was significantly lower in 2015 (Kruskal-Wallis, p < 0.05) with no differences between scenarios.

When discriminating dry and wet years, according to the different nitrogen and phosphorus inputs simulated, one can note on Figure 4 that oyster production values were maximized for a mass ratio $\mathrm{N}: \mathrm{P}$ of the watershed contributions around 8.3 (that is, about $100 \mathrm{t} \mathrm{N}$ for $12 \mathrm{t} \mathrm{P}$ or a molar ratio of 18.4 ; Figure 4$)$.
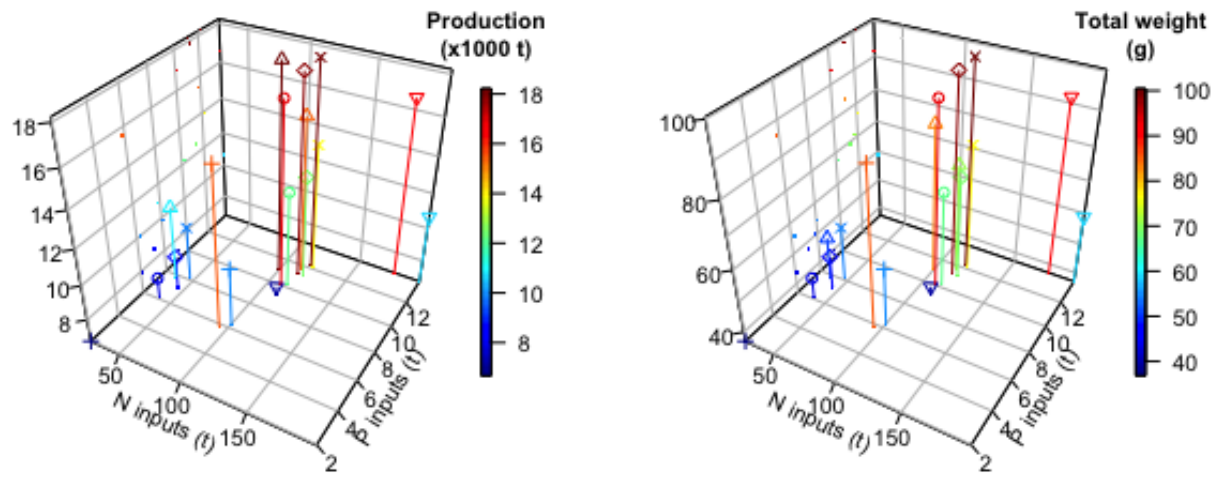

- Ref

$\triangle$ Max dens

+ Max yield

$\times$ Nal yield

$\checkmark$ SCOT

$\nabla$ Sète

Figure 4. 3D scatter plot of production $\left(10^{3} \mathrm{t}\right)$ and total weight $(\mathrm{g})$ of oysters as function of $\mathrm{N}$ and $\mathrm{P}$ inputs $(\mathrm{t})$ according to scenarios and years (see legend inset).

This seemingly optimal N:P ratio was obtained for the scenarios varying nutrient loadings "Nal yield" (n³), "SCOT" (n²) and "Reference" during" wet years (2014 \& 2016) but not during 2015 (Table 2) where N:P ratio was 6.6. 
In fact, the nitrogen inputs according to the different scenarios during the dry year (2015) varied from $25 \%$ to $50 \%$ of those during the two wet years (2014 and 2016) with the largest difference between dry and wet years recorded for the "Max. yield" scenario (Table 2). For phosphorus, the variability of the contributions according to the hydrometeorology was less marked. Nevertheless, inputs of phosphorus in the dry year were 1.5 to 3 times lower than for wet years. This difference between wet and dry years was also largely marked by a significant modification of the contribution of the WWTP to the total inputs of the watershed reaching $89 \%$ on average in a dry year. Nitrogen to phosphorus mass ratios of inputs varied from 4.6 to 16.0 (10-35 mol:mol) depending on the year and scenario and encompassed the optimal 8.3 $\mathrm{N}: \mathrm{P}$ value linked to the highest oyster productions obtained in our simulations.

\subsection{Carrying capacity}

While renewal time (RT) seemed constant and corresponded to 48.6 days (Table 2), phytoplankton biomass renewal time (PPT) and clearance time (CT) varied according to scenarios with minimal and maximal means observed for "Max density" and "Normal yield" scenarios respectively (Table 2). The CT:RT ratio remained constant regardless of the nutrient loading scenario (mean of 0.38) and was lower as part of the "Max density" scenario (mean 0.30), indicating that water renewal times exceeded clearance times. The CT:PPT ratios ranged from 2.06 to 2.93 with minimal mean observed at "Max density" (Table 2, Figure 5), indicating that shellfish culture pressure on phytoplankton was not critical, because clearance time was of $34 \%$ to $50 \%$ of phytoplankton production potential. In other words, the renewal time of phytoplankton production in the Thau lagoon was systematically twice as fast as the time required for oysters to filter all the phytoplankton biomass produced. This "Max. density" scenario led to the lowest CT:PPT ratios with values of 2.13, 2.45 and 1.98 for 2014, 
2015 and 2016 respectively, revealing a stronger pressure of shellfish farming on its phytoplankton resources than the other scenarios.

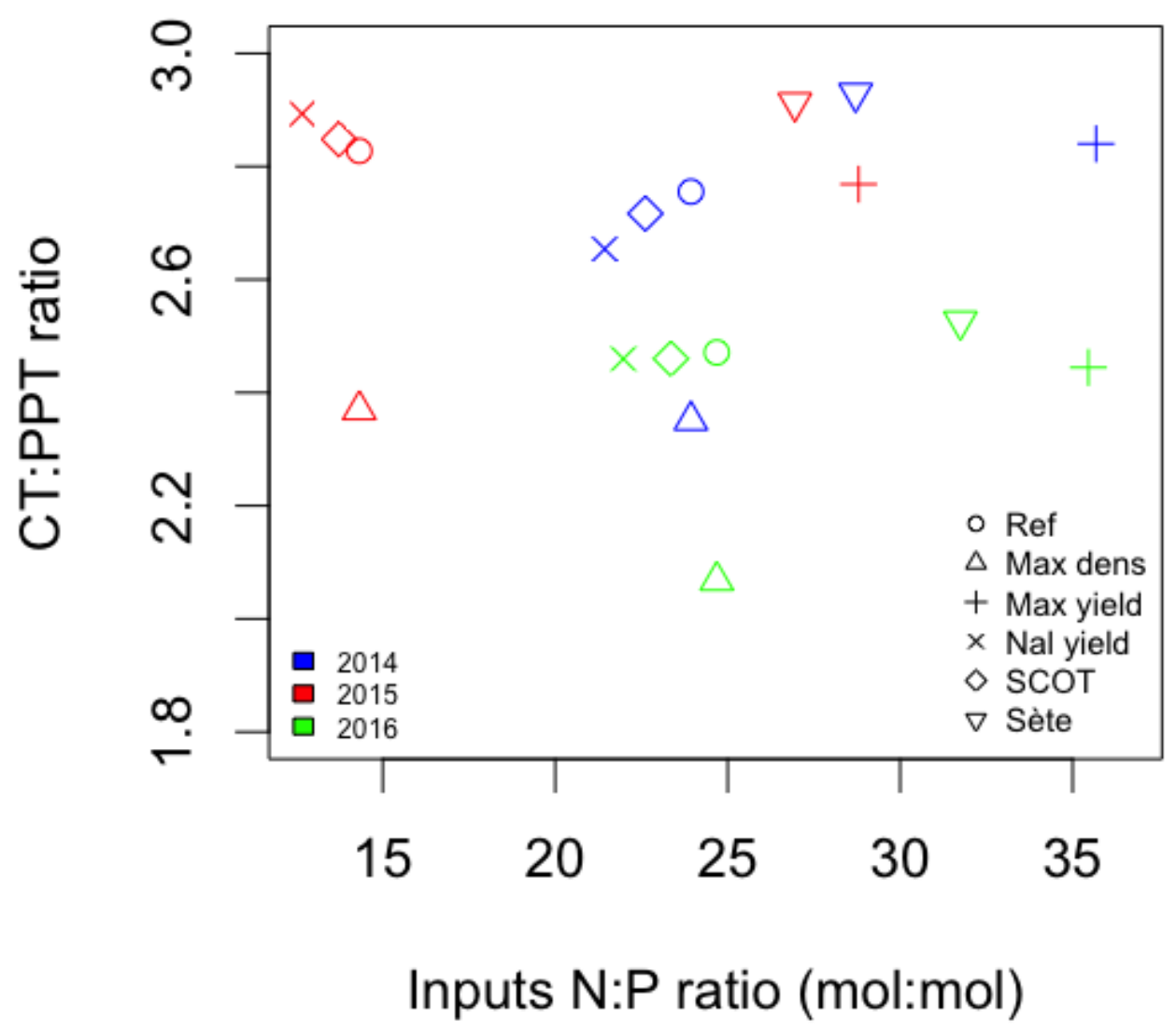

Figure 5. Clearance time to phytoplankton renewal time ratio as a function of inputs N:P molar ratios plotted for the 3 simulated years and all scenarios (see legend inset).

This pressure was accompanied by the lowest lagoon-scale phytoplankton depletion index over these three simulated years (Table 2). The CT:RT and CT:PPT ratios showed no significant correlation with $\mathrm{N}: \mathrm{P}$ ratio of catchment inputs.

For the "Reference" scenario presented (Figure 6), the median value of this index varied between $-14 \%$ and $-13 \%$ indicating that the lagoon was in slight depletion conditions but may support shellfish production. The median lagoon-scale depletion indices appeared consistently negative, regardless of the scenario tested (Figure 6-A, B \& C). Overall median lagoon-scale 
depletion indices varied between -12.3 and $-15.1 \%$ depending on the year and scenarios tested, but they did not show a clear trend depending on the amount of nitrogen or phosphorus brought by the watershed (Figure 6- A and B). The range of values of the median depletion index was bounded by the scenarios "Max. density" and "Max. yield". The difference between simulated years was the main contrast between these median values of the depletion index (Kruskal-Wallis, p-value $<0.01$ ). Figure 6-C showed these median depletion indices as a function of the N:P ratios of the catchment contributions and the values of these indices decreased with decreasing N:P ratio of watershed inputs in 2015 and 2016 (Spearman correlation coefficient of -0.83 and -0.94 , respectively).
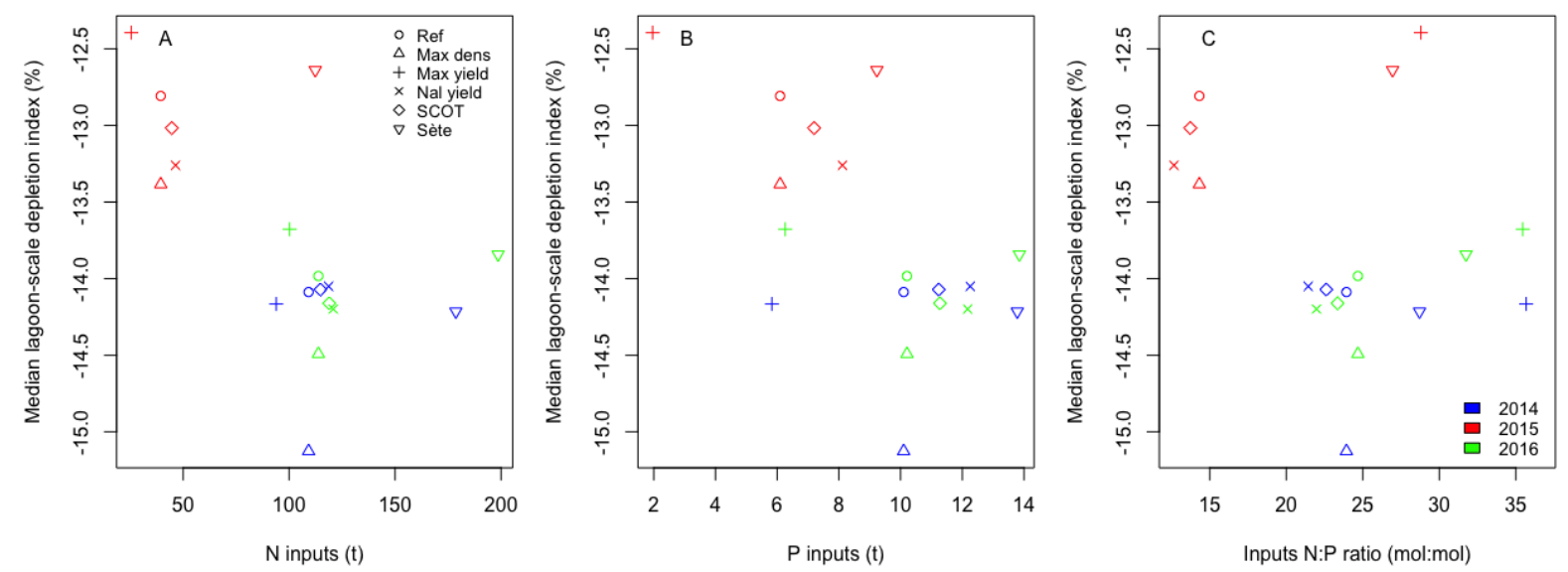

Figure 6. Median lagoon-scale depletion index expressed as a function of $\mathrm{N}$ inputs (A), $\mathrm{P}$ inputs (B) and inputs N:P molar ratio $(\mathrm{C})$.

\subsection{Ecological Status}

Although carrying capacity can be assessed through different indices, ecological status of the lagoon must be regarded as another major characteristic depending on nutrient loadings or shellfish culture practices. The p90 summer concentrations of DIN, DIP, TN and TP, derived from the "Reference" simulations (Figure 7-A, B \& C) were consistent with the concentrations observed in the water column of Thau lagoon in the context of the 2011-2016 WFD diagnosis (concentrations measured: 0.2, 0.2, 22.2, $0.9 \mu \mathrm{mol}^{-1} \mathrm{r}^{-1}$ respectively) (Derolez 
et al., 2017). DIN p90 were significantly higher (Kruskal-Wallis, p-value < 0.001) in 2015 $($ mean $=0.49)$ than in 2014 and 2016 (mean: 0.31 and 0.33 , respectively), regardless of the scenario tested.
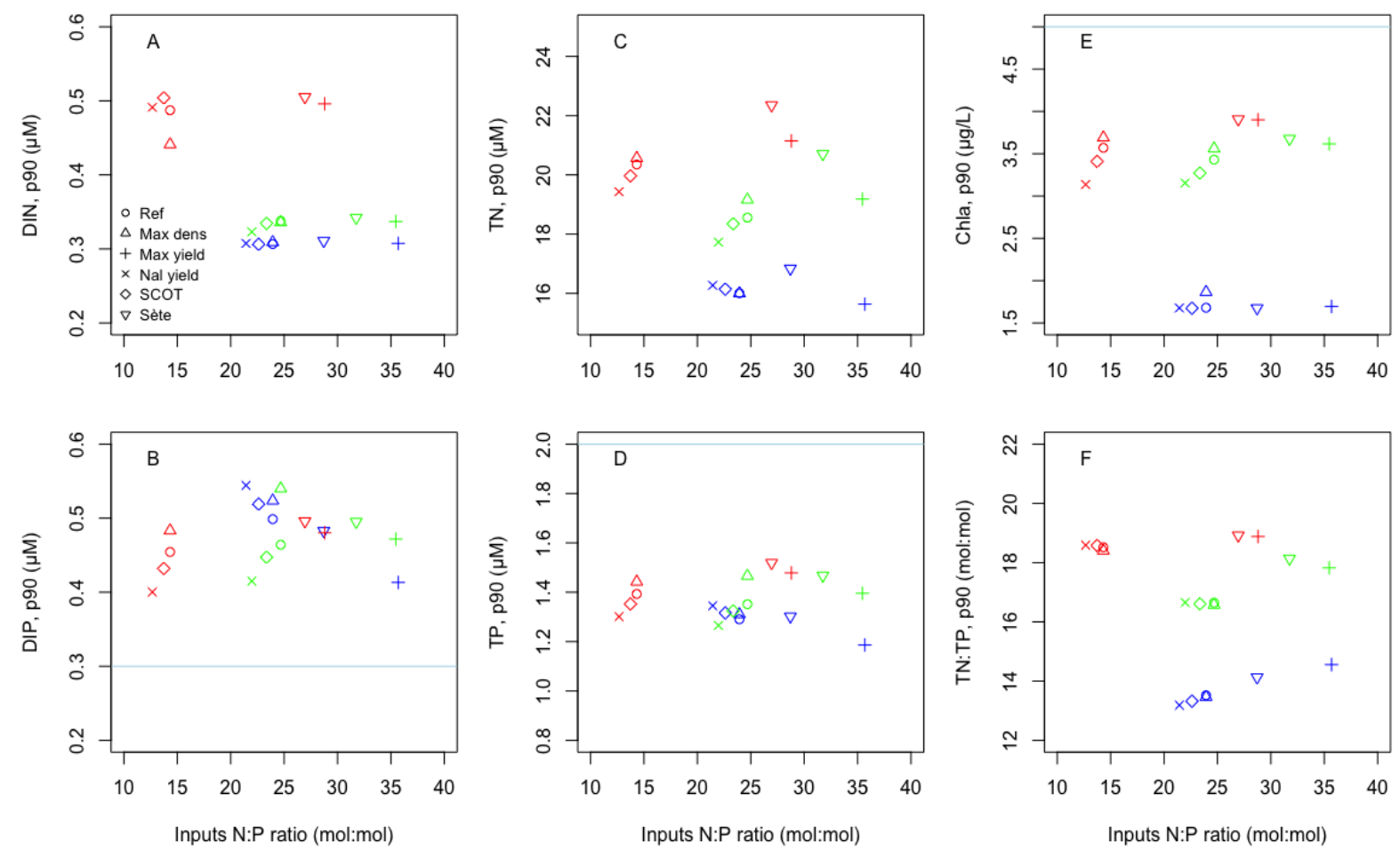

Figure 7. $90^{\text {th }}$ percentiles for DIN (A), DIP (B), TN (C), TP (D), Chl $a(\mathrm{E})$ and TN:TP ratio (F) as a function of inputs N:P molar ratio for all scenarios (see legend in Figure A inset). Colors correspond to simulated years (2014: blue, 2015: red, 2016: green). High/Good ecological status thresholds according to WFD are represented by blue lines for DIP, TP and Chl $a$. These thresholds were not visible for DIN $(2 \mu \mathrm{M})$ and $\mathrm{TN}(50 \mu \mathrm{M})$.

TN p90 were contrasted between years with significant differences recorded between 2014 and the two other years 2015 and 2016 (Kruskal-Wallis, p-value < 0.001). Finally, Chl $a$ p90 were found significantly lower (Kruskal-Wallis, p-value < 0.001) in $2014\left(\right.$ mean $\left.=1.71 \mu \mathrm{g} .1^{-1}\right)$ than 2015 and 2016 (mean $=3.60$ and $3.45 \mu \mathrm{g} \cdot \mathrm{l}^{-1}$, respectively).

However, the model seemed to underestimate TN values (17.6 and $20.4 \mu \mathrm{mol} . \mathrm{l}^{-1}$ for the "Reference" scenario, n=92 and all scenarios, n=552, respectively). Nitrogen and Phosphorus inputs, associated with the different scenarios, did not seem to affect the ecological diagnosis 
of the water column based on nutrient indicators as none of these scenarios triggered a modification of ecological status classes. These simulated indicators gave p90 values in agreement with the "High" status fixed by WFD (MEDDE, 2015), in accordance with the High status evaluated by 2011-2016 WFD diagnosis. Only simulated DIP concentrations were classified in the "good" ecological status for all scenarios (Table 2). Shellfish production at harvest, for all scenarios, decreased significantly for a given year when the N:P ratio of catchment contributions increased (Figure 8-A). These relationships have a Spearman correlation coefficient of $-0.75,-0.98$ and -0.90 for years 2014,2015 and 2016 respectively (p-value $<0.05$ for the three relationships) although no significant relationship has been established between shellfish production and nitrogen inputs or phosphorus inputs independently.
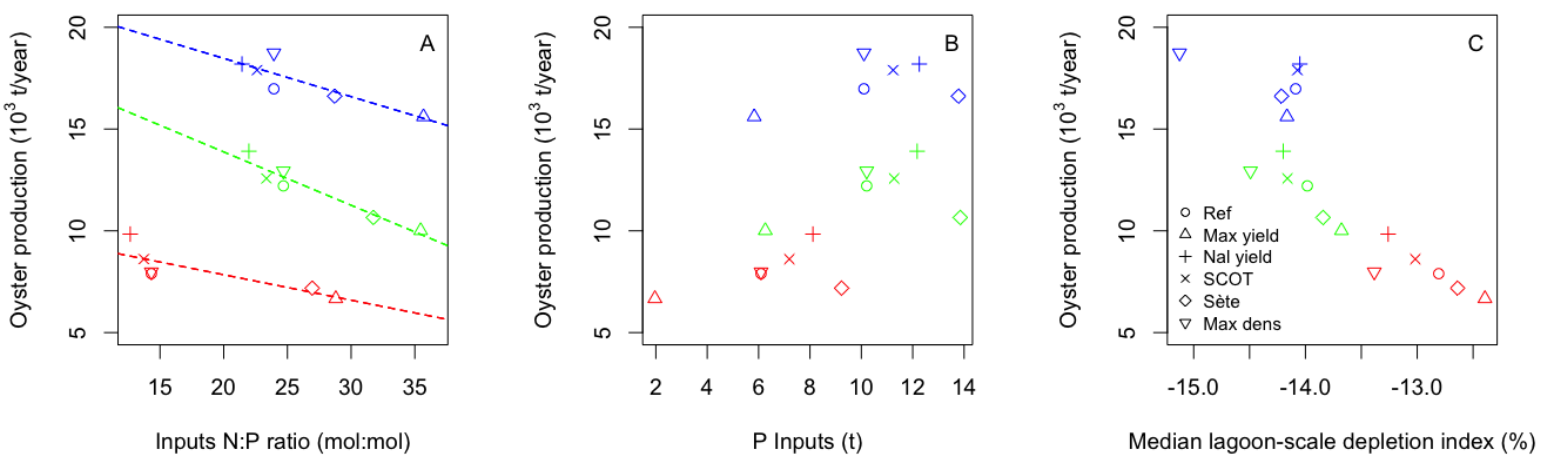

Figure 8. Oyster production as a function of (A) inputs N:P ratio, (B) phosphorus inputs and (C) median lagoon-scale depletion index for the three years (2014: blue, 2015: red, 2016: green) and all scenarios (see legend inset).

In addition, production was negatively correlated with the median lagoon-scale depletion index, but this relationship was not linear for a given year (Fig. 8-B).

The "Max. Dens." Scenario $\left(n^{\circ} 6\right)$ had the lowest median depletion index (Figure 8-B) indicating that it had more impact on phytoplankton biomass than scenarios with comparable production outputs (ie "Nal Yield", scenario n $\left.{ }^{\circ} 3\right)$. On the other hand, the "Max. yield" $\left(\mathrm{n}^{\circ} 2\right)$ and "Sète" ( $\left.\mathrm{n}^{\circ} 5\right)$ scenarios gave the highest median depletion indexes but at the expense of 
lower oyster productions. The comparison of nitrogen and phosphorus quantities added to the lagoon in each of the three simulated years showed the role of the hydro-meteorology on oyster production.

\section{Discussion}

The GAMELag-Conch model was developed to address the questions related to the management of the Thau lagoon ecosystem with regards to the issues of shellfish production and ecological status regulations. Scenarios tested were developed from realistic management hypotheses. These hypotheses included leverages on the quantities of nitrogen and phosphorus potentially available through waste water treatment plant management or on the quantities of cultured filter feeders introduced in farming zones.

\subsection{Scenarios and oyster performances}

All scenarios tested in this study were based on achievable management objectives. In this respect, little difference was highlighted from oyster performance model outputs when comparing scenarios. Although, nutrient loadings, in terms of nitrogen and phosphorus, were varying with these different scenarios, the highest increase in oyster production was recorded at $+25 \%$ ("Normal yield" scenario) in 2015 in comparison to "Reference". This specific case corresponded to the modification of the Mèze WWTP efficiency, going from maximum to normal abatements, and a very dry year $(2015,-200 \mathrm{~mm})$ where WWTP effluents were the main contributors to nutrient loadings $(+7 \mathrm{t} \mathrm{N}$ and $+2 \mathrm{t} \mathrm{P})$. To a lesser extent, "SCOT" and "Max. density" scenarios also demonstrated an increase in oyster production but limited to +3 to $+9 \%$ and +1 to $+10 \%$, respectively. The effect of increased nutrient loadings, mainly nitrogen, on the production of cultured filter feeders has already been reported in modelling studies (Ferreira et al., 2007; Guyondet et al., 2014; Rose et al., 2015). On the opposite, 
reducing nutrient loadings from the watershed (scenario "Max yield" in this study) through the improvement of waste water treatment efficiency triggered a loss in production between $8 \%$ and $-18 \%$ compared to our "Reference" scenario further indicating this dependence of oyster farming on nutrient supply of the Thau system. However, the variation in nutrient loadings quantity may not solely explain the response of cultured oyster as large addition of nitrogen $(+171 \%)$ in the "Sète" scenario rendered lower oyster production than "Reference" ($2 \%$ to $-13 \%$ ). This effect is probably linked to the joint influence of nitrogen and phosphorus additions, the location of these inputs and the response of the biological compartments and is further discussed below. In terms of oyster performances, scenarios associated with increased nutrient loadings demonstrated that oysters marginally gained in length, quality (condition index) and total weight at harvest but remained in the same market grade (66-85 g; according to the French 6 grades weight where $n^{\circ} 5: 30-45 g, n^{\circ} 4: 46-65 g, n^{\circ} 3: 66-85 g, n^{\circ} 2: 86-110 g$, $\mathrm{n}^{\circ} 1: 111-150 \mathrm{~g}$ and $\mathrm{n}^{\circ} 0$ : over $\left.151 \mathrm{~g}\right)$. However, a reduction of, as well as unbalanced, nutrient loadings, produced smaller oysters and a modification of the market grade (46-65 g) with potential repercussion on economic aspects (Ferreira et al., 2007). Finally, "Max. density" scenario demonstrated higher oyster production but at the expenses of thinner oysters with lower condition index. This scenario highlighted the density effect where an increased abundance triggered a competition for the resources yielding smaller individuals (Gangnery et al., 2001; Gangnery, 2003; Filgueira et al., 2014b).

The scenarios tested here have revealed differences in terms of oyster performances and productions, however, major contrasts were brought by interannual variability where dry against wet years triggered the largest variations in nutrient loadings. Consequently, oyster productions were significantly lower in years presenting evident rainfall deficit. Oyster lengths, total weight and condition index were also significantly affected with smaller, lighter and lower quality during dry years. Nevertheless, oyster production and performances 
evaluated through this modelling work shall be replaced within the context of ecological status and ecological carrying capacity to better assess overall functioning of the ecosystem (Byron et al., 2011b; Higgins et al., 2011).

\subsection{Trophic carrying capacity and ecological status}

One of the objectives of this work was to assess the carrying capacity of the Thau lagoon regarding to shellfish farming within the frame of WFD regulation. The Thau lagoon, as any other shellfish farming sites, is characterized by complex dynamics of interacting biological and physical processes. Within these systems, filter feeding activity may deeply modify the energy fluxes as they clear large volume of water including suspended particles (Dowd, 2003; Filgueira et al., 2014a).

To evaluate the capability of an ecosystem to support various uses, it is important to compare phytoplankton production, phytoplankton biomass, lagoon hydrodynamics as well as shellfish culture pressure to truly highlight the limits of the ecosystem. A first approach using these different aspects of the functioning of the ecosystem is the Dame index (Dame and Prins., 1998). This index relates the characteristic times RT (renewal time), CT (clearance time) and PPT (phytoplankton biomass renewal time) of the Thau lagoon. The CT:RT ratio indicates whether filter feeders and its resources are controlled by exchanges with the sea or by internal (including inputs from the watershed) availability of nutrients. The GAMELag-Conh model was able to simulate oyster productions along with indicators of the ecological status, depletion index and characteristic times (CT, RT, PPT) comparatively with different scenarios of nutrient inputs and shellfish cultures. The relationships between oyster production and the carrying capacity of the lagoon was evaluated with regards to the Dame index, particularly the CT:PPT ratio, and the lagoon-scale phytoplankton depletion index. Both markers demonstrated a top-down control of filter feeders on phytoplankton population. In this study, 
simulated clearance and water renewal times, CT and RT, indicated that hydrodynamic exchanges with the far field (outside the lagoon) were not efficient enough to drive the filter feeder resources. Therefore, phytoplankton dynamic or its bottom-up control, would rather be driven by nutrients coming from the watershed. In comparison, the Marennes-Oléron site (Bacher, 1989; Dame and Prins., 1998; Raillard and Menesguen, 1994) showed slower phytoplankton biomass renewal times and much faster filtration capacity resulting in a system that did appear to be largely under pressure (Marennes-Oléron CT:PPT $=0.27$ ) despite a more efficient hydrodynamics than in the Thau lagoon (Marennes-Oléron RT $=7.1$ ). The simulated values of the CT:PPT ratio suggested that the consumption of phytoplankton biomass by farmed oysters was constrained between 34 and 50\%, leaving half, or more, of the phytoplankton stock available for other trophic levels. Trousselier \& Deslous-Paoli (2001) had also concluded that Thau lagoon was productive in the 1990s, with shellfish harvested production representing about 3\% of primary production. Dame and Prins (1998) postulated that successful shellfish population occur when RT is less than 40 days and PPT below 4 days. If characteristic times calculated for the Thau lagoon are longer than these recommended times, shellfish cultures have prospered in the Thau lagoon and its carrying capacity did not seem to be threatened. Both ratios, CT:RT and CT:PPT, expressed the state of the carrying capacity of the lagoon by comparing the characteristic times of physics, phytoplankton, and shellfish in culture (Table 2). However, they do not consider the presence of nutritive resources other than phytoplankton such as zooplankton or particulate organic matter. The model outputs indicated that oyster production is related to the input N:P molar ratio with production increasing with decreasing N:P ratios. These linear relationships were contrasted between years, highlighting the strong influence of the hydrological regime and hence the quantities of nitrogen and phosphorus entering the lagoon. These first relationships were bounded by the maximum WWTP yield and normal WWTP yield scenarios as they 
provided the highest and lowest input N:P molar ratio, respectively. This also revealed that, if filter feeder production might be increased by decreasing the N:P ratio of inputs, the amount of nutrients coming from the watershed, most probably phosphorus, would limit the maximum levels of production to be reached. The shellfish productions were also increasing with decreasing lagoon-scale depletion index indicating that more production would trigger higher depletion of the Thau system. Once again, the most apparent contrast was linked to the different simulated years where higher nutrient loadings generated higher shellfish productions and hence an increased pressure on its phytoplankton resource. N:P ratio of loadings, however, was similar in 2014 and 2016, whereas phytoplankton summer biomass was similar in 2015 and 2015. Therefore, higher oyster production and subsequent increased filter feeder pressure could not only be explained by nutrient loadings. Annual mean temperature anomaly, compared to the $1970-2016$ mean $\left(15.3^{\circ} \mathrm{C}\right)$ was $+1.5^{\circ} \mathrm{C},+1.4^{\circ} \mathrm{C}$ and $+1.1^{\circ} \mathrm{C}$ for 2014,2015 and 2016 respectively. In previous modelling studies (Filgueira et al., 2016), increased temperature has been identified as a key factor in enhancing grazer activity through higher metabolism with concomitant higher pressure on phytoplankton. The highest oyster production simulated in 2014 would be in agreement with highest annual average temperature recorded in 2014 for the Thau lagoon. In addition, 2015 was associated with low nutrient inputs, which resulted in low oyster performances, even if temperature anomaly was similar to 2014. In this second relationship (e.g. oyster production against depletion index), oyster production was bounded by the maximum oyster densities and the maximum WWTP yield scenarios. The use of maximum allowed stocking densities generated the highest depletion in agreement with the density effect (Chapelle et al., 2000; Grant et al., 2007; Grangeré et al., 2010).

The increase in the quantities of seeded shellfish did not lead to significantly higher harvests compared to the "Reference" scenario (1 to 10\%). Moreover, the shellfish thus produced were 
smaller, probably because of the competition for the nutritive resource between growing individuals. This scenario also exhibited the lowest CT:PPT ratios indicating a noticeable pressure of farmed oysters on their phytoplankton resource. Accordingly, highest depletion was recorded when increasing stocking densities, which corroborates this impact on phytoplankton stock. However, Chl $a$ concentrations, used in the ecological status evaluation, were not lower in the presence of higher densities of filter feeders than with the other scenarios. This might be explained either by the fact that: 1) energy stocks of filter feeders during the summer are allocated to spawning rather than nutrition (e.g. filtration), or 2) the increase in cultured bivalve density may have a positive feedback effect on phytoplankton outside growing structures through more excretion of inorganic nutrients (Filgueira et al., 2014b; Kellogg et al., 2014).

It is important to note that shellfish farming activities occupy about $20 \%$ of the Thau lagoon area ( $\sim 30 \%$ by volume) which is probably a criterion of its durability. In agreement with the occupational state of the Thau lagoon, Byron et al (2011b) reported, using the Ecopath model on the Narragansett bay, another example of a low-intensity of shellfish cultures where carrying capacity is not reached due to high nutrient loadings and primary productivity. These authors evaluated that if shellfish cultures density remained at current levels, the growing area might theoretically be extended up to $26 \%$ of the bay area without exceeding the ecological carrying capacity. On the contrary, the study by Filgueira et al. (2014), concerning a bay occupied at $80 \%$ in volume by the mussel farms, showed a strong impact on the phytoplankton resource, where the median bay-scale depletion index $(-34.2 \%)$ was below the sustainable threshold calculated from natural variability of Chl $a$ concentration (-27.5\%). This shellfish farming pressure was also reported, to a lesser extent, in Saint Peter's Bay (Guyondet et al, 2015), where only the central part of the bay exhibited depletion for a total farmed area of $40 \%$. 
The simulated ecological indicators were chosen to correspond to the observations used in the WFD diagnosis (EC, 2000). Regardless of scenarios or simulated years, these ecological indicators fell into the "high" ecological status class. Only, simulated DIP concentrations exceeded the "high" to "good" threshold $(0.3 \mu \mathrm{M})$, hence placing the ecological status of the lagoon into the "good" conditions for the water column chemistry. The comparison of simulated years or scenarios showed significant differences for DIN between dry and wet years with higher concentrations recorded during the dry year (2015) and for Chl $a$ where concentrations in 2015 and 2016 were found higher than in 2014. The main concluding remarks on this ecological status evaluation is that scenarios tested in this study did not altered the ecological status of the lagoon. In addition to this fulfilling "high" ecological status, weak phytoplankton depletion and the moderate pressure of cultured oysters on their resources, the current oyster production (“Ref”, scenario n¹), oscillating between 7900 and 17000 tons, would therefore be sustainable and not conflicting with EU regulation nor are opposed to the important efforts made to reduce nutrient inputs from the watershed. Indeed, ecological carrying capacity appears as a major component in the evaluation of the whole ecosystem functioning and should be carefully considered at the same level as ecological status.

\subsection{Control of lagoon phytoplankton and shellfish productivity}

The results obtained in this modeling work of the Thau lagoon seemed to indicate a control of the system by the nitrogen and phosphorus inputs from the watershed and more precisely by the $\mathrm{N}: \mathrm{P}$ ratio of these inputs. When the inputs related to the various scenarios are detailed, it appeared that if the $\mathrm{N}$ inputs from the watershed covered a wide range of values (25.5 to 198.6 tons), the variability of phosphorus inputs was much smaller (1.8 to 13.8 tons). The variability of $\mathrm{N}$ and $\mathrm{P}$ inputs related to the hydrometeorological regime seemed the main 
driver for the variability of shellfish production. Increases of $57 \%$ and $27 \%$ in $\mathrm{N}$ and $\mathrm{P}$ inputs during wet years led to a $36 \%$ increase in predicted oyster production.

By replacing shellfish production at harvest in the context of nitrogen and phosphorus inputs for all scenarios and the three simulated years, an optimum of the N:P inputs molar ratio appeared ( 18.4) around which the oyster productions seemed to be maximized (in 2014 and 2016, wet years). Current loadings ("Reference"), both natural and anthropogenic, are just over 100 tons of nitrogen in wet years $(2014,2016)$ for a phosphorus input of about 10 tons, bringing the $\mathrm{N}: \mathrm{P}$ molar ratio above 22 . To obtain a molar ratio of inputs around 18.4 , it would therefore be necessary to bring an additional 2.5 tons of $\mathrm{P}$ into the system (ie 12.5 tons of $\mathrm{P}$ in total). Phosphorus appeared to be insufficient and therefore limiting if one considers these current contributions of nitrogen. The "Sète" scenario $\left(n^{\circ} 5\right)$ confirmed the hypothesis of a phosphorus-controlled system, where a misleading excess of nitrogen $(\sim+100$ tons $)$ did not help to achieve higher production because this scenario increased the phosphorus deficit in the system. Although more $\mathrm{P}$ was brought to the lagoon, oyster production did decrease in comparison with "reference" scenario. The "Sète" scenario tested the response of the ecosystem to excess $\mathrm{N}$ and P loading from a WWTP. In the current situation, this WWTP releases its wastewater into the sea. This scenario involved the release of waste waters into box 1 ("Petit étang") of the model. Box 1 is the box connected with the sea, hence part of these inputs is exchanged with the sea, the other part reached box 2 then box 3 where cultured areas are located. In the "Sète" scenario, the model shows that sediment has accumulated more $\mathrm{N}$ (times 2.5) and has released less P (times 0.4 ) in box 1 than the "Reference". Along with the sediment compartment, macroalgae, notably Ulva and Gracilaria, yielded higher biomasses (times 2 and times 1.5 for Ulva and Gracilaria respectively) than in the reference scenario. This may indicate that macrophytes enter a competition for nutrients in box $1 . \mathrm{N} \&$ $\mathrm{P}$ in sediment and macroalgae did not show marked differences in all other boxes of the 
model. Nevertheless, this would indicate that box 1 was the first to respond to these additional inputs. Remaining nitrogen and phosphorus were then exchanged with the sea and with box 2 and further up. Macrophytes competing for nutrient resources and a greater accumulation of matter may have led to a lower P availability in boxes 2 and 3 including farming areas (boxes 4 and 5) and hence lower oyster production.

$\mathrm{N}$ inputs $(\mathrm{N}), \mathrm{P}$ inputs $(\mathrm{P})$ and $\mathrm{N}: \mathrm{P}$ ratio of inputs (NP) were used in a PCA analysis (Figure 9) along with shellfish culture performances variables such as production (Prod), total weight at harvest (P_tot) or condition index (CI) and ecosystem functioning variables as chlorophyll $a$ concentration in and out oyster farming zones (Chla_OF and Chla_out, respectively) or the lagoon-scale phytoplankton depletion index (DI). Phosphorus inputs were strongly correlated with shellfish performances (first axis, $71.51 \%$ of variance explained) and chlorophyll $a$ concentrations, suggesting a key role of phosphorus in controlling both phytoplankton and oyster production.
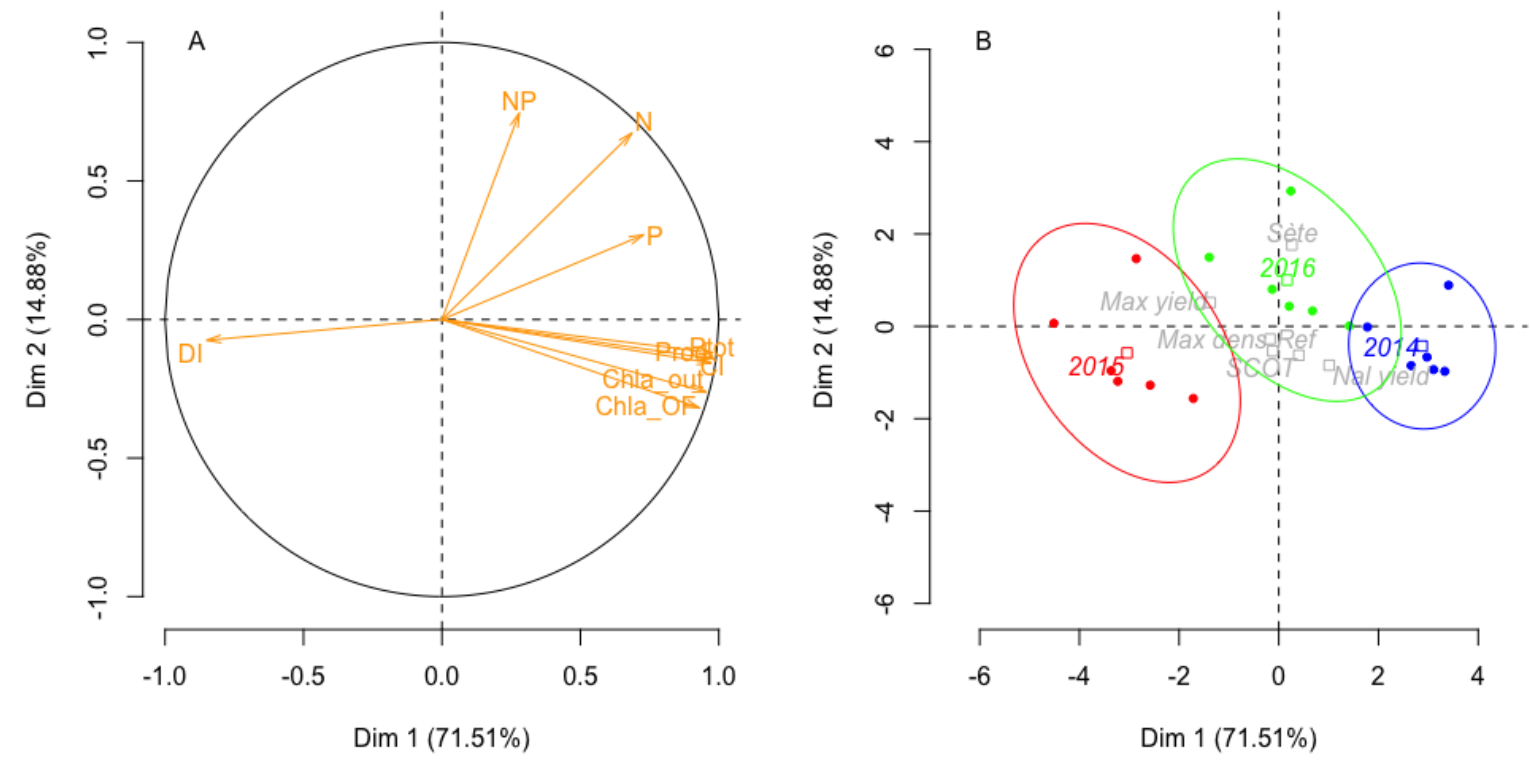

Figure 9. PCA analysis (A) of model outputs including nitrogen inputs $(\mathrm{N})$, phosphorus inputs $(\mathrm{P})$, inputs $\mathrm{N}: \mathrm{P}$ ratio (NP), oyster production (Prod), oyster total weight ( $\mathrm{P} \_$tot), condition index (CI), Chl a concentration in (Chla_OF) and outside (Chla_out) oyster farms and the median lagoon-scale phytoplankton depletion index (DI). Supplementary qualitative variables (B) representing simulated 
years with coloured 95\% confidence interval ellipses (individuals: dots and barycentre: square) and scenarios (named grey squares).

The phosphorus inputs were inversely correlated with the depletion index, indicating also a role in regulating the carrying capacity of the Thau lagoon. Nitrogen to phosphorus ratio of inputs, and to a lesser extent nitrogen inputs, explained the second dimension of this PCA analysis (14.88\% of variance explained; Figure 9-A) suggesting that, if phosphorus may control production levels importantly, the balance between nitrogen and phosphorus in loadings carried from the watershed had a major importance in the efficiency of the Thau ecosystem and hence on its trophic carrying capacity. Supplementary variables, as simulated years and simulated scenarios, once placed in this PCA (Figure 9-B), demonstrated the major importance of contrasted hydrological conditions as suggested above, whereas the variability linked to the scenarios tested in this study exhibited less difference between scenarios with no clear pattern.

Deslous-Paoli et al. (1998) reported this control of shellfish production by phosphorus in the 1990s, where the oyster stocking density was around 25 to 30000 tons of shellfish and for an annual production exceeding 15000 tons (against 9200 to 9500 tons currently reported by shellfish farmers). This study also reported phosphate concentrations in water 40 times higher than the current concentrations ( $4 \mu \mathrm{M}$ against $0.1 \mu \mathrm{M})$. At the same time, even though the concentrations of $\mathrm{PO}_{4}{ }^{3-}$ in water have been decreasing since the $1970 \mathrm{~s}$, the significant expansion of oyster farming during this period (from 1400 to 2440 tables in 20 years) would have reduced the risk of eutrophication by removing about $30 \%$, according to the authors, of this readily available phosphorus from the Thau lagoon. At present, the decrease in phosphorus inputs from the watershed and, consequently, the concentrations in the water column, is mainly attributed to the major efforts made on the waste water treatment systems (Derolez et al., 2013; La Jeunesse, 2001; Souchu et al., 2010). Depending on the year, the 
contribution of anthropogenic inputs from WWTP varies importantly to supply up to $90 \%$ of total inputs in dry years. The N:P molar ratio of these anthropogenic inputs $(\sim 5 ; 2009-2016$ average, data not shown) is much lower than that of natural inputs ( 40; 2009-2016 average, data not shown), thus placing the lagoon in nitrogen limiting conditions in those years, the main source of current phosphorus inputs coming from the WWTPs.

\section{Conclusions}

The GAMELag-Conch model, developed to answer the problem of reconciling resource exploitation through shellfish culture and regulatory constraints, allowed an evaluation of the ecosystem carrying capacity of the Thau lagoon and the simulation of various scenarios waste water treatment management and shellfish farming strategies. To the best of our knowledge, there are no existing model taking into account both nitrogen and phosphorus inputs within the frame of carrying capacity assessment and most carrying capacity models are based solely on nitrogen (Dowd, 2003; Byron et al., 2011c; Chapelle et al., 2000; Filgueira et al., 2014a; Guyondet et al., 2014) or biomass data sets (Jiang and Gibbs, 2005). Under current conditions, the carrying capacity of the Thau Lagoon does not appear to be limiting. The interannual variability introduced by the differences in weather conditions strongly affects shellfish farming in terms of production and shellfish performances rather than did the contrast between the different tested scenarios. The productivity of the ecosystem seemed to depend mainly on watershed inputs in which inputs from WWTPs had a predominant role in dry years. Shellfish production was more specifically controlled by phosphorus as revealed by unbalanced N:P ratio in loadings. The trophic resource being sufficient, the oyster control on the phytoplankton was not excessive and depended on the stock density of cultured bivalves or additional phosphorus brought to the lagoon. The use of high stocking densities should be prohibited because if they generated higher production than current conditions, at the 
expenses of thinner oysters with low condition index. Finally, the ecological status did not appear to be threatened with regard to the current shellfish pressure. This model thus appeared as a suitable tool for management perspectives. Another strength and recommended approach (Byron et al., 2011a) of this work resides in the implication of shellfish farmers, stakeholders, local and governmental management bodies as well as scientists to implement realistically based scenarios in the search for an equilibrium between shellfish production and ecological status regulation.

However, important caveats must be given here as this paper reports a global evaluation of the carrying capacity through the use of characteristic times or depletion index that might vary in time and space (Dame and Prins., 1998; Guyondet et al., 2014). Further work is necessary to alleviate this time varying control of the carrying capacity where characteristic times or even depletion index are used to identify seasonal effects and sensitive periods to be confronted to shellfish production, performances and potential ecological impacts. This ongoing work shall help management of shellfish culture practices in this context of maintaining "good" ecological status. A perspective use of this numerical tool resides in a theoretical approach that would involve large variations of nutrient loadings to seek for tipping points where depletion or ecological indicators may drastically change with strong impacts on the whole ecosystem functioning. Short term development of this tool would address the question of anoxic crisis, which had sporadically occurred in the Thau lagoon when temperature increases and weather conditions are calm. These anoxic crises have led to dramatic loss of cultured bivalves hence temporarily damaging ecological conditions of the lagoon. Further developments of this management tool should address questions related to climate change, where the frequency and-or the intensity of meteorological events, such as temperature increase or the modification of rainfall regimes should be considered concomitantly with 
increase in population, in turn increasing watershed loadings, subsequent refit of WWTP and sustainability of uses in the Thau lagoon.

\section{Acknowledgements}

This study was supported by the University of Montpellier, Ifremer and DLAL-FEAMP (CAPATHAU postdoctoral fellowship). The authors thank Melaine Gourault for providing the latest version of the DEB model for Crassostrea gigas. Thanks to Eve Mouret for adapting this model to the Thau Lagoon oysters as part of her Master thesis, and Christophe Lett for his help in her supervision. We express our gratitude to all the staff of the LER-LR laboratory, involved in the observation networks of the REPHY, the RESCO, the RSL-DCE, specifically Claude Chiantella, Eric Abadie, Clarisse Hubert, Serge Mortreux, Patrik le Gall, Gregory Messiaen, Anais Crottier, Elodie Foucault, Martine Fortune, Dominique Munaron, Tom Berteaux, Jocelyne Oheix, Emmanuelle Roque d'Orbcastel and the coordinators of these networks (Catherine Belin, Elodie Fleury, Valérie derolez). Our thanks also go to the SMBT for providing the database of nitrogen and phosphorus inputs from the watershed. The authors also thank the DLAL animators (Beatrice Pary, Agnes D'Artigues) and the people involved in the scenario construction (SMBT: Luc Hardy, David Cottalorda, CRCM: Denis Regler, Adeline Perignon, Cepralmar: Matthew Hebert, Erika Gervasoni, Anahita Marzin, DDTM: Philian Retif, AERMC: Anahi Barrera, Anais Giraud).

\section{References}

Alunno-Bruscia, M., Bourlès, Y., Maurer, D., Robert, S., Mazurié, J., Gangnery, A., Goulletquer, P., Pouvreau, S., 2011. A single bio-energetics growth and reproduction model for the oyster Crassostrea gigas in six Atlantic ecosystems. J. Sea Res. 66, 340-348. https://doi.org/10.1016/j.seares.2011.07.008 
Bacher, C., 1989. Capacité trophique du bassin de Marennes-Oléron : couplage d'un modèle de transport particulaire et d'un modèle de croissance de l'huître Crassostrea gigas. Aquat. Living Resour. 2, 199-214. https://doi.org/10.1051/alr:1989025

Bacher, C., Duarte, P., Ferreira, J.G., Héral, M., Raillard, O., 1998. Assessment and comparison of the Marennes-Oléron Bay (France) and Carlingford Lough (Ireland) carrying capacity with ecosystem models. Aquat. Ecol. 31, 379-394.

\section{https://doi.org/10.1023/A:1009925228308}

Bec, Béatrice, Valérie Derolez, Dominique Soudant, Ludovic Cesmat, Romain Pete, and Marion Richard. 2018. Projet CAPATHAU : Capacité Trophique de la lagune de Thau. Evolution temporelle de l'état écologique de la lagune de Thau et des performances des coquillages en élevage au regard de la réduction des apports issus du bassin versant et des changements météo. 58 p.

Bernard, I., de Kermoysan, G., Pouvreau, S., 2011a. Effect of phytoplankton and temperature on the reproduction of the Pacific oyster Crassostrea gigas: Investigation through DEB theory. J. Sea Res. 66, 349-360. https://doi.org/10.1016/j.seares.2011.07.009 Bernard, I., de Kermoysan, G., Pouvreau, S., 2011b. Effect of phytoplankton and temperature on the reproduction of the Pacific oyster Crassostrea gigas: Investigation through DEB theory. J. Sea Res. 66, 349-360. https://doi.org/10.1016/j.seares.2011.07.009 Bougrier, S., Geairon, P., Deslous-Paoli, J.M., Bacher, C., Jonquières, G., 1995. Allometric relationships and effects of temperature on clearance and oxygen consumption rates of Crassostrea gigas (Thunberg). Aquaculture 134, 143-154. https://doi.org/10.1016/00448486(95)00036-2

Bourlès, Y., Alunno-Bruscia, M., Pouvreau, S., Tollu, G., Leguay, D., Arnaud, C., Goulletquer, P., Kooijman, S. a L.M., 2009. Modelling growth and reproduction of the Pacific oyster Crassostrea gigas: Advances in the oyster-DEB model through application to a coastal 
pond. J. Sea Res. 62, 62-71. https://doi.org/10.1016/j.seares.2009.03.002

Brigolin, D., Maschio, G.D., Rampazzo, F., Giani, M., Pastres, R., 2009. An individual-based population dynamic model for estimating biomass yield and nutrient fluxes through an offshore mussel (Mytilus galloprovincialis) farm. Estuar. Coast. Shelf Sci. 82, 365-376. https://doi.org/10.1016/j.ecss.2009.01.029

Byron, C., Bengtson, D., Costa-Pierce, B., Calanni, J., 2011a. Integrating science into management: Ecological carrying capacity of bivalve shellfish aquaculture. Mar. Policy 35, 363-370. https://doi.org/10.1016/j.marpol.2010.10.016

Byron, C., Link, J., Costa-Pierce, B., Bengtson, D., 2011b. Calculating ecological carrying capacity of shellfish aquaculture using mass-balance modeling: Narragansett Bay, Rhode Island. Ecol. Modell. 222, 1743-1755. https://doi.org/10.1016/j.ecolmodel.2011.03.010 Byron, C., Link, J., Costa-Pierce, B., Engtson, D., 2011c. Modeling ecological carrying capacity of shellfish aquaculture in highly flushed temperate lagoons. Aquaculture 314, 8799. https://doi.org/10.1016/j.aquaculture.2011.02.019

Carver, C.E.A., Mallet, A.L., 1990. Estimating the carrying capacity of a coastal inlet for mussel culture. Aquaculture 88, 39-53. https://doi.org/10.1016/0044-8486(90)90317-G Chapelle, A., Ménesguen, A., Deslous-Paoli, J.M., Souchu, P., Mazouni, N., Vaquer, A., Millet, B., 2000. Modelling nitrogen, primary production and oxygen in a Mediterranean lagoon. Impact of oysters farming and inputs from the watershed. Ecol. Modell. 127, 161181. https://doi.org/10.1016/S0304-3800(99)00206-9

Dabrowski, T., Lyons, K., Curé, M., Berry, A., Nolan, G., 2013. Numerical modelling of spatio-temporal variability of growth of Mytilus edulis (L.) and influence of its cultivation on ecosystem functioning. J. Sea Res. 76, 5-21. https://doi.org/10.1016/j.seares.2012.10.012 Dame, R.E., Prins., T.C., 1998. Bivalve carrying capacity in coastal ecosystems. Aquatic Ecology 31(4):409-421. 409-421. 
Derolez, V., Ouisse, V., Fiandrino, A., Munaron, D., Bissery, C., Kloareg, M., 2013. Analyse statistique des données du RSL - Etude des trajectoires écologiques des lagunes entre 2001 et 2012.

DDTM. 2014. Arrêté nº DDTM34-2016-06-04069 du 19 juin 2014 portant Schéma des structures des autorisations d'exploitation de cultures marines situées dans le Département de l'Hérault. http://www.cepralmar.org/guide_conchylicole/documents/2.1.2-

\section{$\underline{\text { Structures_Herault.pdf }}$}

Deslous-Paoli, J.M., Souchu, P., Mazouni, N., Juge, C., Dagault, F., 1998. Relations milieuressources: Impact de la conchyliculture sur un environnement lagunaire Mediterraneen (Thau). Oceanol. Acta 21, 831-843. https://doi.org/10.1016/S0399-1784(99)80010-3

Dowd, M., 2003. Seston dynamics in a tidal inlet with shellfish aquaculture: A model study using tracer equations. Estuar. Coast. Shelf Sci. 57, 523-537. https://doi.org/10.1016/S02727714(02)00397-9

European Community, 2000. Directive 200/60/EC of the European parliament and of the council of 23 October 2000 establishing a framework for community action in the field of water policy.

European Community, 1991, Council Directive 91/676/EEC of 12 December 1991 concerning the protection of waters against pollution caused by nitrates from agricultural sources.

European Community, 2004. Case C-280/02. Commission of the European Communities v French Republic. Failure of a Member State to fulfil obligations - Directive 91/271/EEC. Urban waste water treatment. Article 5(1) and (2) and Annex II. Failure to identify sensitive areas. Meaning of "eutrophication". Failure to implement more stringent treatment of discharges into sensitive areas. https://eur-lex.europa.eu/legalcontent/EN/TXT/HTML/?uri=CELEX:62002CJ0280\&from=FR 
Fao, 2018. World Fisheries and Aquaculture, Aquaculture. https://doi.org/issn 10

Ferreira, J.G., Hawkins, A.J.S., Bricker, S.B., 2007. Management of productivity, environmental effects and profitability of shellfish aquaculture - the Farm Aquaculture Resource Management (FARM) model. Aquaculture 264, 160-174. https://doi.org/10.1016/j.aquaculture.2006.12.017

Ferreira, J.G., Hawkins, A.J.S., Monteiro, P., Moore, H., Service, M., Pascoe, P.L., Ramos, L., Sequeira, A., 2008. Integrated assessment of ecosystem-scale carrying capacity in shellfish growing areas. Aquaculture 275, 138-151. https://doi.org/10.1016/j.aquaculture.2007.12.018 Fiandrino, A., Giraud, A., Robin, S., \& Pinatel, C. (2012). Validation d'une méthode d'estimation des volumes d'eau échangés entre la mer et les lagunes et définition d'indicateurs hydrodynamiques associés.

Fiandrino, A., Ouisse, V., Dumas, F., Lagarde, F., Pete, R., Malet, N., Le Noc S., de Wit, R. (2017). Spatial patterns in coastal lagoons related to the hydrodynamics of seawater intrusion. Marine Pollution Bulletin, 119(1), 132-144. http://doi.org/10.1016/j.marpolbul.2017.03.006 Filgueira, R., Comeau, L. a, Guyondet, T., Mckindsey, C.W., Byron, C.J., 2015. Modelling carrying capacity of bivalve aquaculture: A review of definitions and methods, Encyclopedia of Sustainability Science and Technology. https://doi.org/10.1007/978-1-4939-2493-6 Filgueira, R., Grant, J., 2009. A box model for ecosystem-level management of mussel culture carrying capacity in a Coastal Bay. Ecosystems 12, 1222-1233. https://doi.org/10.1007/s10021-009-9289-6 Filgueira, R., Guyondet, T., Comeau, L. a., Grant, J., 2014a. A fully-spatial ecosystem-DEB model of oyster (Crassostrea virginica) carrying capacity in the Richibucto Estuary, Eastern Canada. J. Mar. Syst. 136, 42-54. https://doi.org/10.1016/j.jmarsys.2014.03.015 Filgueira, R., Guyondet, T., Comeau, L.A., Grant, J., 2014b. Physiological indices as indicators of ecosystem status in shellfish aquaculture sites. Ecol. Indic. 39, 134-143. 
https://doi.org/10.1016/j.ecolind.2013.12.006

Filgueira, R., Guyondet, T., Comeau, L.A., Tremblay, R., 2016. Bivalve aquacultureenvironment interactions in the context of climate change. Glob. Chang. Biol. 22, 3901-3913. https://doi.org/10.1111/gcb.13346

Gangnery, A., 2003. Etude et modélisation de la dynamique des populations de bivalves en élevage (Crassostrea gigas et Mytilus galloprovincialis) dans le bassin de Thau (Méditerranée, France) et des ascidies solitaires associées. Phd Thesis 1-175.

Gangnery, A., Bacher, C., Buestel, D., 2001. Assessing the production and the impact of cultivated oysters in the Thau lagoon (Mediterranee, France) with a population dynamics model. Can. J. Fish. Aquat. Sci. 58, 1012-1020. https://doi.org/10.1139/f01-028

Grangeré, K., Lefebvre, S., Bacher, C., Cugier, P., Ménesguen, A., 2010. Modelling the spatial heterogeneity of ecological processes in an intertidal estuarine bay: Dynamic interactions between bivalves and phytoplankton. Mar. Ecol. Prog. Ser. 415, 141-158. https://doi.org/10.3354/meps08659

Grangeré, K., Ménesguen, A., Lefebvre, S., Bacher, C., Pouvreau, S., 2009. Modelling the influence of environmental factors on the physiological status of the Pacific oyster Crassostrea gigas in an estuarine embayment; The Baie des Veys (France). J. Sea Res. 62, 147-158. https://doi.org/10.1016/j.seares.2009.02.002

Grant, J., Curran, K.J., Guyondet, T.L., Tita, G., Bacher, C., Koutitonsky, V., Dowd, M., 2007. A box model of carrying capacity for suspended mussel aquaculture in Lagune de la Grande-Entrée, Iles-de-la-Madeleine, Québec. Ecol. Modell. 200, 193-206. https://doi.org/10.1016/j.ecolmodel.2006.07.026

Grant, J., Filgueira, R., 2011. The application of dynamic modelling to prediction of production carrying capacity in shellfish farming., in: Shumway, S. (Ed.), Shellfish Aquaculture and the Environment. Wiley-Blackwell Science Publishers, Ames, IA, pp. 135- 
154.

Guyondet, T., Comeau, L. a., Bacher, C., Grant, J., Rosland, R., Sonier, R., Filgueira, R., 2014. Climate Change Influences Carrying Capacity in a Coastal Embayment Dedicated to Shellfish Aquaculture. Estuaries and Coasts 38, 1593-1618. https://doi.org/10.1007/s12237014-9899-х

Guyondet, T., Roy, S., Koutitonsky, V.G., Grant, J., Tita, G., 2010. Integrating multiple spatial scales in the carrying capacity assessment of a coastal ecosystem for bivalve aquaculture. J. Sea Res. 64, 341-359. https://doi.org/10.1016/j.seares.2010.05.003 Harzallah, A., Chapelle, A., 2002. Influence de la variabilité climatique sur l' apparition de crises anoxiques ou 'malaïgues' dans l' étang de Thau (sud de la France). Oceanol. Acta 25, 79-86. https://doi.org/10.1016/s0399-1784(02)01184-2

Higgins, C.B., Stephenson, K., Brown, B.L., 2011. Nutrient Bioassimilation Capacity of Aquacultured Oysters: Quantification of an Ecosystem Service. J. Environ. Qual. 40, 271. https://doi.org/10.2134/jeq2010.0203

Jiang, W., Gibbs, M.T., 2005. Predicting the carrying capacity of bivalve shellfish culture using a steady, linear food web model. Aquaculture 244, 171-185.

https://doi.org/10.1016/j.aquaculture.2004.11.050

Kashiwai, M., 1998. History of carrying capacity concept as an index of ecosystem productivity: (Review). Bull. Hokkaido Natl. Fish. Res. Inst. 59, 81-100.

Kellogg, M.L., Smyth, A.R., Luckenbach, M.W., Carmichael, R.H., Brown, B.L., Cornwell, J.C., Piehler, M.F., Owens, M.S., Dalrymple, D.J., Higgins, C.B., 2014. Use of oysters to mitigate eutrophication in coastal waters. Estuar. Coast. Shelf Sci. 151, 156-168. https://doi.org/10.1016/j.ecss.2014.09.025

Kooijman, S.A.L.M., 2010. Dynamic energy budget theory and population ecology: lessons from Daphnia. Philos. Trans. R. Soc. B Biol. Sci. 365, 3541-3552. 


\section{https://doi.org/10.1098/rstb.2010.0167}

Kooijman, S.A.L.M., 2009. Dynamic Energy Budget Theory 514.

Lagarde, F., Fiandrino, A., Ubertini, M., D’Orbcastel, E.R., Mortreux, S., Chiantella, C., Bec,

B., Bonnet, D., Roques, C., Bernard, I., Richard, M., Guyondet, T., Pouvreau, S., Lett, C., 2019. Duality of trophic supply and hydrodynamic connectivity drives spatial patterns of Pacific oyster recruitment. Mar. Ecol. Prog. Ser. https://doi.org/10.3354/meps13151

La Jeunesse, I., 2001. Etude intégrée dynamique du phosphore dans le système bassin versant-lagune de Thau.

La Jeunesse, I., Elliott, M., 2004. Anthropogenic regulation of the phosphorus balance in the Thau catchment-coastal lagoon system (Mediterraean Sea, France) over 24 years. Mar. Pollut. Bull. 48, 679-687. https://doi.org/10.1016/j.marpolbul.2003.10.011

McKindsey, C.W., Thetmeyer, H., Landry, T., Silvert, W., 2006. Review of recent carrying capacity models for bivalve culture and recommendations for research and management. Aquaculture 261, 451-462. https://doi.org/10.1016/j.aquaculture.2006.06.044 Ministère de 1'Ecologie, du Développement Durable et de l'Energie (MEDDE), 2015. Arrêté du 27 juillet 2015 modifiant l'arrêté du 25 janvier 2010 relatif aux méthodes et critères d'évaluation de l'état écologique, de l'état chimique et du potentiel écologique des eaux de surface pris en application des articles R. 212-10, R. 212-11 et R. 212-18 du Code de l'Environnement. JORF n0198, p. 15032.

https://www.legifrance.gouv.fr/eli/arrete/2015/7/27/DEVL1513989A/jo/texte.

Nunes, J.P., Ferreira, J.G., Gazeau, F., Lencart-Silva, J., Zhang, X.L., Zhu, M.Y., Fang, J.G., 2003. A model for sustainable management of shellfish polyculture in coastal bays. Aquaculture 219, 257-277. https://doi.org/10.1016/S0044-8486(02)00398-8

Parsons, T.R., Stephens, K., Strickland, J.D.H., 1961. On the Chemical Composition of Eleven Species of Marine Phytoplankters. J . Fish . Res . Bd . Can . Downloaded from 
www.nrcresearchpress.com by WAGENINGEN UR on 09 / 08 / 15.

Pernet, F., Barret, J., Le Gall, P., Corporeau, C., Dégremont, L., Lagarde, F., Pépin, J.F., Keck, N., 2012. Mass mortalities of Pacific oysters Crassostrea gigas reflect infectious diseases and vary with farming practices in the Mediterranean Thau lagoon, France. Aquac. Environ. Interact. 2, 215-237. https://doi.org/10.3354/aei00041

Platt, T., Irwin, B., 1973. Caloric content of phytoplankton. Limnol. Oceanogr. 18, 306-310. https://doi.org/10.4319/lo.1973.18.2.0306

Plus, M., Jeunesse, I. La, Bouraoui, F., Zaldívar, J.M., Chapelle, A., Lazure, P., 2006. Modelling water discharges and nitrogen inputs into a Mediterranean lagoon: Impact on the primary production, in: Ecological Modelling. pp. 69-89.

https://doi.org/10.1016/j.ecolmodel.2005.07.037

Pouvreau, S., Bourles, Y., Lefebvre, S., Gangnery, A., Alunno-Bruscia, M., 2006. Application of a dynamic energy budget model to the Pacific oyster, Crassostrea gigas, reared under various environmental conditions. J. Sea Res. 56, 156-167.

https://doi.org/10.1016/j.seares.2006.03.007

Raillard O., Ménesguen A., 1994. An ecosystem box-model for estimating the carrying capacity of a macrotidal shellfish system. Mar.Ecol.Prog.Ser. 115, 117-130.

REPHY. 2017. French Observation and Monitoring program for Phytoplankton and Hydrology in coastal waters. 1987-2016 Metropolitan data. SEANOE database (http://doi.org/10.17882/47248).

Rose, J.M., Bricker, S.B., Ferreira, J.G., 2015. Comparative analysis of modeled nitrogen removal by shellfish farms. Mar. Pollut. Bull. 91, 185-190.

https://doi.org/10.1016/j.marpolbul.2014.12.006

Smaal, A.C., Prins, T.C., Dankers, N., Ball, B., 1997. Minimum requirements for modelling bivalve carrying capacity. Aquat. Ecol. 31, 423-428. 
https://doi.org/10.1023/A:1009947627828

Soetaert, K., Petzoldt, T., Setzer, R.W., 2010. Package deSolve : Solving Initial Value Differential Equations in R. J. Stat. Softw. 33, 1-25.

Souchu, P., Bec, B., Smith, V.H., Laugier, T., Fiandrino, A., Benau, L., Orsoni, V., Collos, Y., Vaquer, A., 2010. Patterns in nutrient limitation and chlorophyll a along an anthropogenic eutrophication gradient in French Mediterranean coastal lagoons. Can. J. Fish. Aquat. Sci. 753, 743-753. https://doi.org/10.1139/F10-018

Souchu, P., Gasc, A., Collos, Y., Vaquer, A., Tournier, H., Bibent, B., Deslous-Paoli, J.M., 1998. Biogeochemical aspects of bottom anoxia in a Mediterranean lagoon (Thau, France). Mar. Ecol. Prog. Ser. 164, 135-146. https://doi.org/10.3354/meps164135

Troussellier, M., Deslous-Paoli, J.M., 2001. La lagune de Thau: un site atelier pour l'acquisition, l'intégration et la valorisation des connaissances. Oceanis 27, 257-289.

Willmott, C.J., 1981. On the validation of models. Phys. Geogr. 2, 184-194. 


\section{SUPPLEMENTARY MATERIAL}

Table S1. Equations describing the energy fluxes and state variable differential equations (after Bernard et al, 2011) in the Dynamic Energy Budget (DEB) model. X corresponds to the oyster food resources, $\mathrm{T}$ to the water temperature $(\mathrm{K})$.

\begin{tabular}{|c|c|c|}
\hline $\mathrm{N}^{\circ}$ & Description & Equation \\
\hline$(\mathrm{S} 1-\mathrm{A})$ & Temperature effect & $\begin{aligned} c_{T}=\exp \left\{\frac{T_{A}}{T_{1}}-\frac{T_{A}}{T}\right\} \cdot\left(1+\exp \left\{\frac{T_{A L}}{T_{1}}-\frac{T_{A L}}{T_{L}}\right\}+\exp \left\{\frac{T_{A H}}{T_{H}}-\frac{T_{A H}}{T_{1}}\right\}\right) \\
\cdot\left(1+\exp \left\{\frac{T_{A L}}{T}-\frac{T_{A L}}{T_{L}}\right\}+\exp \left\{\frac{T_{A H}}{T_{H}}-\frac{T_{A H}}{T}\right\}\right)^{-1}\end{aligned}$ \\
\hline$(\mathrm{S} 1-\mathrm{B})$ & Ingestion rate & $\dot{p}_{X}=\left\{\dot{j}_{X m}\right\} \cdot f \cdot V^{2 / 3} \cdot c_{T} \cdot T_{i m}$ \\
\hline$\left(\mathrm{S} 1-\mathrm{B}^{\prime}\right)$ & Functional response & $f=\frac{X}{X+K(Y)}$ \\
\hline$(\mathrm{S} 1-\mathrm{B}, ')$ & Food composition & $X=\alpha_{P S} P S+\alpha_{P L} P L+\alpha_{Z S} Z S+\alpha_{Z S} Z L+\alpha_{P O M} P O M$ \\
\hline$(\mathrm{S} 1-\mathrm{C})$ & Assimilation rate & $\dot{p}_{A}=\kappa_{X} \cdot \dot{p}_{X}$ \\
\hline$(\mathrm{S} 1-\mathrm{D})$ & Reserve mobilization rate & $\dot{p}_{C 1}=[E] \frac{c_{T}\left[E_{G}\right] \dot{v} V^{2 / 3}+c_{T}\left[\dot{p}_{M}\right]}{\kappa[E]+\left[E_{G}\right]}$ with $[E]=E / V$ \\
\hline$(\mathrm{S} 1-\mathrm{E})$ & Structural maintenance rate & $\dot{p}_{M 1}=\left[\dot{p}_{M}\right] \cdot V \cdot c_{T}$ \\
\hline$(\mathrm{S} 1-\mathrm{F})$ & Structural growth rate & $\dot{p}_{G}=\kappa \cdot \dot{p}_{C 1}-\dot{p}_{M}$ \\
\hline (S1-G) & Maturity maintenance rate & $\dot{p}_{J}=\min \left(V, V_{P}\right) \cdot\left[\dot{p}_{M}\right] \cdot\left(\frac{1-\kappa}{\kappa}\right) \cdot c_{T}$ \\
\hline$(\mathrm{S} 1-\mathrm{H})$ & Maturation and reproduction rate & $\dot{p}_{R}=(1-\kappa) \cdot \dot{p}_{C 1}-\dot{p}_{J}$ \\
\hline$(\mathrm{S} 1-\mathrm{I})$ & Lysis of structure rate & $\dot{p}_{L 1}=\max \left(\dot{p}_{M 1}-\left(\kappa \dot{p}_{C 1}+\dot{p}_{M 2}+\dot{p}_{L 2}\right), 0\right)$ \\
\hline$(\mathrm{S} 1-\mathrm{J})$ & Gamete mobilization rate & $\dot{p}_{C 2}=E_{R}\left(\frac{\left\{\dot{p}_{A m}\right\} \cdot c_{T}}{[E m] \cdot V^{1 / 3}}+\frac{\left[\dot{p}_{M}\right] \cdot c_{T}}{\left[E_{G}\right]}\right) \cdot\left(1-\kappa \cdot \frac{E}{\left[E_{G}\right] \cdot V+\kappa \cdot E}\right)$ \\
\hline$(\mathrm{S} 1-\mathrm{K})$ & Emergency maintenance rate & $\dot{p}_{M 2}=\min \left(\dot{p}_{M 1}-\kappa \dot{p}_{C 1}, \dot{p}_{C 2}\right)$ \\
\hline$(\mathrm{S} 1-\mathrm{L})$ & Gonad allocation rate & $\dot{p}_{G o}=\dot{p}_{C 2}-\dot{p}_{M 2}$ \\
\hline$(\mathrm{S} 1-\mathrm{M})$ & Gamete resorption rate & $\dot{p}_{L 2}=\max \left(\frac{\dot{p}_{M 1}-\kappa \cdot \dot{p}_{C 1}+\dot{p}_{M 2}}{Y_{G o}}, 0\right)$ \\
\hline$(\mathrm{S} 1-\mathrm{N})$ & Total dry flesh mass calculation & $D F M=\frac{E+E_{R}}{\mu_{E}}+V \cdot d_{V}+\frac{E_{G o} \cdot d_{G o}}{\left[E_{G g o}\right]}$ \\
\hline \multicolumn{3}{|c|}{ State variable differential equations } \\
\hline$(\mathrm{S} 1-\mathrm{O})$ & Reserves & $\frac{d E}{d t}=\dot{p}_{A}-\dot{p}_{c 1}$ \\
\hline$(\mathrm{S} 1-\mathrm{P})$ & Structural volume & $\frac{d V}{d t}=\frac{\dot{p}_{G}-\dot{p}_{L 1}}{\left[E_{G}\right]}$ \\
\hline$(\mathrm{S} 1-\mathrm{Q})$ & Development/reproduction & $\frac{d E_{R}}{d t}=\dot{p}_{R}-\dot{p}_{c 2}$ \\
\hline$(\mathrm{S} 1-\mathrm{R})$ & Gametes & $\frac{d E_{G O}}{d t}=\dot{p}_{G O}-\dot{p}_{L 2}-$ spawning \\
\hline
\end{tabular}


Table S2. Dynamic Energy Budget (DEB) parameters used in the present study based on

Pouvreau et al, 2006 and Bernard et al, 2011.

\begin{tabular}{|c|c|c|c|}
\hline Parameter description & Symbol & Value & Unit \\
\hline \multicolumn{4}{|l|}{ Main parameters } \\
\hline Shape coefficient & $\delta_{M}$ & 0.175 & - \\
\hline Maximum surface specific ingestion rate & $\left\{\dot{p}_{X m}\right\}$ & 1025 & $\mathrm{~J} \mathrm{~cm}^{-2} \mathrm{~d}^{-1}$ \\
\hline Volume specific maintenance cost & {$\left[\dot{p}_{M}\right]$} & 44 & $\mathrm{~J} \mathrm{~cm}^{-3} \mathrm{~d}^{-1}$ \\
\hline Volume specific cost for structural growth & {$\left[E_{G}\right]$} & 3900 & $\mathrm{~J} \mathrm{~cm}^{-3}$ \\
\hline Maximum reserve density & {$\left[E_{m}\right]$} & 4200 & $\mathrm{~J} \mathrm{~cm}^{-3}$ \\
\hline Allocation fraction to growth and maintenance & $\mathrm{\kappa}$ & 0.45 & - \\
\hline Assimilation efficiency & $\kappa_{\mathrm{X}}$ & 0.75 & - \\
\hline Reproduction efficiency & $\kappa_{G o}$ & 0.90 & - \\
\hline $\mathrm{N}$ food half saturation coefficient (spat - oyster) & $X k_{N}$ & $5-2$ & mmol. $1^{-1}$ \\
\hline$P$ food half saturation coefficient & $X k_{P}$ & $0.5-0.1$ & $\mathrm{mmol} .1^{-1}$ \\
\hline \multicolumn{4}{|l|}{ Additional and compound parameters } \\
\hline Energy content of $1 \mathrm{~g}$ of reserve & $\mu_{E}$ & 19600 & $\mathrm{~J} \mathrm{~g}^{-1}$ \\
\hline Dry mass ratio of structure & $d_{V}$ & 0.15 & $\mathrm{~g}_{\mathrm{dw}} \mathrm{g}_{\mathrm{ww}}{ }^{-1}$ \\
\hline Dry mass ratio of gonad & $d_{G O}$ & 0.31 & $\mathrm{~g}_{\mathrm{dw}} \mathrm{g}_{\mathrm{ww}}{ }^{-1}$ \\
\hline Volume specific cost for gonad & {$\left[E_{G g o}\right]$} & 7500 & $\mathrm{~J} \mathrm{~cm}^{-3}$ \\
\hline Energy yield of gonad & $\mu_{60}$ & 21630 & $\mathrm{~J} \mathrm{~g}_{\mathrm{dw}}{ }^{-1}$ \\
\hline Energy conductance & $\dot{v}=\kappa_{X}\left\{\dot{p}_{X m}\right\} /\left[E_{m}\right]$ & 0.183 & $\mathrm{~cm} \mathrm{~d}^{-1}$ \\
\hline Yield of gonad tissue used for maintenance & $Y_{g o}$ & 0.25 & - \\
\hline Shell length at puberty & $L_{p}$ & 4.2 & $\mathrm{~cm}^{3}$ \\
\hline Percentage of immersion & $T_{i m}$ & 1 & - \\
\hline Gonado-somatic index triggering spawning & $R G S$ & 0.35 & - \\
\hline $\mathrm{N}$ to $\mathrm{P}$ stoichiometry of oyster & $N P_{O}$ & 10 & mol:mol \\
\hline \multicolumn{4}{|l|}{ Parameters linking DEB to biogeochemistry } \\
\hline Conversion factor of non-assimilated food & $C_{\text {oyster }}$ & 3250 & $\mathrm{~J}$ mmolN ${ }^{-1}$ \\
\hline Energy yield of reserve & $\mu_{E N}$ & 3667 & $\mathrm{~J}$ mmolN ${ }^{-1}$ \\
\hline Preference for small phytoplankton & $\alpha_{\mathrm{PS}}$ & 0.6 & - \\
\hline Preference for large phytoplankton & $\alpha_{\mathrm{PL}}$ & 0.5 & - \\
\hline Preference for small zooplankton & $\alpha_{\mathrm{ZS}}$ & 0.4 & - \\
\hline Preference for large zooplankton & $\alpha_{\mathrm{ZL}}$ & 0.2 & - \\
\hline Preference for particulate organic nitrogen & $\alpha_{\mathrm{PON}}$ & 0.1 & - \\
\hline Preference for particulate organic phosphorus & $\alpha_{\mathrm{POP}}$ & 0.1 & - \\
\hline \multicolumn{4}{|l|}{ Temperature effect } \\
\hline Temperature threshold triggering spawning & $T_{\text {Spawn }}$ & 296.15 & $\mathrm{~K}$ \\
\hline Arrhenius temperature & $T_{A}$ & 5800 & $\mathrm{~K}$ \\
\hline Reference temperature & $T_{1}$ & 293 & $\mathrm{~K}$ \\
\hline Lower boundary tolerance range & $T_{L}$ & 281 & $\mathrm{~K}$ \\
\hline Upper boundary tolerance range & $T_{H}$ & 298 & $\mathrm{~K}$ \\
\hline Arrhenius temp. for lower boundary & $T_{A L}$ & 75000 & $\mathrm{~K}$ \\
\hline Arrhenius temp. for upper boundary & $T_{A H}$ & 30000 & $\mathrm{~K}$ \\
\hline
\end{tabular}


Table S3. Conversion of non-assimilated and dissipated energy within the DEB model.

\begin{tabular}{|c|c|c|c|}
\hline $\mathrm{N}^{\circ}$ & Description & Equation & Units \\
\hline (S3-A) & \multirow{3}{*}{ Faeces } & Feces $_{N}=\left(1-\kappa_{Y}\right) \cdot \dot{p}_{X} \cdot n$ nb of individuals & \multirow{3}{*}{$\operatorname{mmolN} \cdot \mathrm{m}^{-3} \cdot \mathrm{d}^{-1}$} \\
\hline & & $\begin{array}{rr}\text { reces }_{N}=\left(1-\kappa_{X}\right) \cdot \overline{C_{\text {oyster }}} & \text { Volume }_{\text {farm zone }} \\
\dot{p}_{X} & \text { nb of individuals }\end{array}$ & \\
\hline$\left(\mathrm{S} 3-\mathrm{A}^{\prime}\right)$ & & Feces $_{P}=\left(1-\kappa_{X}\right) \cdot \frac{P_{X}}{C_{\text {oyster }} \cdot N P_{X}} \cdot \frac{\text { Volume }_{\text {farm zone }}}{\text { Vol }_{\text {of }}}$ & \\
\hline (S3-B) & \multirow{2}{*}{$\begin{array}{l}\text { Regeneration of } \\
\text { excess nitrogen or } \\
\text { phosphorus }\end{array}$} & $N_{\text {regen }}=\left\{\begin{array}{c}\frac{\dot{p}_{A}}{C_{\text {oyster }}} \cdot\left(1-N P_{O} \cdot \frac{1}{N P_{X}}\right) \text { if } N P_{X}>N P_{O} \\
0 \text { if } N P_{X}<N P_{O}\end{array}\right.$ & \multirow{2}{*}{$\begin{array}{l}\text { mmolN.m-3.- } d^{-1} \\
\text { mmolP.m } m^{-3} \cdot d^{-1}\end{array}$} \\
\hline (S3-B') & & $P_{\text {regen }}=\left\{\begin{array}{c}\frac{\dot{p}_{A}}{C_{\text {oyster }}} \cdot\left(\frac{1}{N P_{X}}-\frac{1}{N P_{O}}\right) \text { if } N P_{X}<N P_{O} \\
0 \text { if } N P_{X}>N P_{O}\end{array}\right.$ & \\
\hline$(\mathrm{S} 3-\mathrm{C})$ & $\begin{array}{l}\text { Conversion of } \\
\text { maintenance costs }\end{array}$ & $C M C=\frac{\dot{p}_{M 1}+\dot{p}_{I}}{\mu_{E N}}$ & mmolN. $\mathrm{m}^{-3} \cdot \mathrm{d}^{-1}$ \\
\hline (S3-D) & Conversion of & $C G C=\frac{\frac{\dot{p}_{G} \cdot\left(\left[E_{G}\right]-d_{V} \cdot \mu_{V}\right)}{\left[E_{G}\right]}}{2}$ & mmolN. $\mathrm{m}^{-3} \cdot \mathrm{d}^{-1}$ \\
\hline & & $\mu_{E N}$ & \\
\hline \multirow[t]{2}{*}{ (S3-E) } & \multirow{2}{*}{$\begin{array}{l}\text { Conversion of } \\
\text { costs of gametes } \\
\text { production }\end{array}$} & $\dot{p}_{G o} \cdot \frac{E_{G o} \cdot d_{G o}}{\left[E_{G g o}\right]}$ & \multirow[t]{2}{*}{$\operatorname{mmolN} \cdot \mathrm{m}^{-3} \cdot \mathrm{d}^{-1}$} \\
\hline & & $\operatorname{CLGP}=\frac{\mu_{E N}}{\mu_{1}}$ & \\
\hline
\end{tabular}

These equations give nutrients excretion in the form of ammonium and orthophosphates, for both oysters and spats according to:

$\mathrm{NH}_{4}^{\text {spat,oyster }}=N_{\text {regen }}+C M C+C G C+C C G P \quad$ Eq. 13

And

$\mathrm{PO}_{4}^{\text {spat,oyster }}=P_{\text {regen }}+\frac{C M C+C G C+C C G P}{N P_{\text {oyster }}} \quad$ Eq. 14

And both equations are integrated in the respective state variable equations $\frac{d \mathrm{NH}_{4}}{d t}$ and $\frac{d \mathrm{PO}_{4}}{d t}$ 